Illinois State University

ISU ReD: Research and eData

Theses and Dissertations

3-29-2021

\title{
The Pedagogy Of Terror: Women'S Education In The Gothic Novel
}

Faith Borland

Illinois State University, faithmborland@gmail.com

Follow this and additional works at: https://ir.library.illinoisstate.edu/etd

Part of the English Language and Literature Commons

\section{Recommended Citation}

Borland, Faith, "The Pedagogy Of Terror: Women'S Education In The Gothic Novel" (2021). Theses and Dissertations. 1352.

https://ir.library.illinoisstate.edu/etd/1352

This Thesis is brought to you for free and open access by ISU ReD: Research and eData. It has been accepted for inclusion in Theses and Dissertations by an authorized administrator of ISU ReD: Research and eData. For more information, please contact ISUReD@ilstu.edu. 


\section{THE PEDAGOGY OF TERROR: WOMEN'S EDUCATION}

\section{IN THE GOTHIC NOVEL}

\section{FAITH BORLAND}

\section{Pages}

This thesis investigates the distinction between terror and horror that Robert Hume first established in his 1969 article on categories of the gothic novel, a distinction that I redefine as a scholar working after the \#Metoo movement and broader cultural recognition of the terror that women face in their everyday lives. "Terror” illustrates the sustained sensations produced in women’s lives as powerless and marginalized. Eighteenth-, nineteenth- and twenty-first-century women writers of the gothic, including Ann Radcliffe, Mary Shelley, and Silvia Moreno-Garcia, depict female characters who overcome terror through domestic, scientific and medical, familial, experiential, cultural, and academic education. Linking recent feminist recuperations of the gothic to foundational conversations about gender in the genre, this thesis expands the idea of education as a defense from terror and argues that the gothic form was and is a kind of pedagogy. KEYWORDS: Gothic; women’s education; terror 


\title{
THE PEDAGOGY OF TERROR: WOMEN'S EDUCATION \\ IN THE GOTHIC NOVEL
}

\author{
FAITH BORLAND
}

\author{
A Thesis Submitted in Partial \\ Fulfillment of the Requirements \\ for the Degree of \\ MASTER OF ARTS \\ Department of English

\section{ILLINOIS STATE UNIVERSITY}


(C) 2021 Faith Borland 


\title{
THE PEDAGOGY OF TERROR: WOMEN'S EDUCATION IN THE GOTHIC NOVEL
}

\author{
FAITH BORLAND
}

COMMITTEE MEMBERS:

Katherine Ellison, Chair

Brian Rejack 


\section{CONTENTS}

Page

CHAPTER I: INTRODUCTION

Education, Women’s Roles, and Businesswomen in the Eighteenth and Nineteenth

Centuries

Female Precursors and the Success of Businesswomen

The Gothic Genre and \#Metoo

CHAPTER II: A HOME EDUCATION: SPATIAL KNOWLEDGE AND TERROR IN ANN

RADCLIFFE'S MYSTERIES OF UDOLPHO

The Role of Education in Preventing and/or Coping with Terror

Knowledge of Space as Power

Conclusion

CHAPTER III: BIRTHING KNOWLEDGE: SHADOW EDUCATION AND

REPRODUCTIVE SCIENCE IN MARY SHELLEY'S FRANKENSTEIN

A Contemporary View of Terror and Education in Birth

The Role of Education in Understanding Male Fear of Women

Claiming the Female Body: Obstetrics vs. Midwifery

Conclusion

CHAPTER IV: THE EVOLUTION OF GOTHIC EDUCATION: INDIGENOUS AND MODERN KNOWLEDGES MIXING IN SILVIA MORENO-GARCIA'S MEXICAN

GOTHIC

Modern Fears of Women’s Education

Modern Science Mixed with Cultural Superstition 
REFERENCES 


\section{CHAPTER I: INTRODUCTION}

Until the scholarship of the 1970s, gothic literature had been firmly divided between the highly praised male works of Horror Gothic and the lesser Terror Gothic written by women. The entrance of women scholars in the 1970s shifted the focus from the canonically accepted works to undervalued writings by women authors; the adherence to canonically accepted works had raised the status of male gothic writers above the geniuses of Mary Shelley, Ann Radcliffe, and Sophia Lee, among others, and had created a false binary to dismiss female works as less serious. Scholarship in the past fifty years has shown that the gothic genre had actually allowed authors to push the limits of gender norms and that gothic situations reflected women's lives and allowed them more freedom and agency in these supernatural and terrifying situations. My thesis will establish the relationship between terror and education as well as explore scholarly articulations of the difference between terror and horror based on gender. I will analyze the gendering of these terms and how that relates to the situations that inspire fear in novels written by men in comparison to novels written by women. As support, my thesis will investigate the distinction between terror and horror that Robert Hume first established in his 1969 article on categories of the gothic novel, a distinction that I will redefine as a scholar working after the \#Metoo movement and broader cultural recognition of the terror that women face in their everyday lives. In Hume's gendering of the gothic, terror is looked down on as lesser than the masculine writing of horror; I, however, recognize that “terror” illustrates the sustained sensations produced in women's lives as powerless and marginalized. I will look at how the education of women relates to their ability to overcome terror and supernatural encounters in gothic novels. Education plays an important role in gothic works by women authors; they highlight educated and enlightened thinking as a crucial defense against superstitious terror (DeLamotte 52). Women writers of the 
gothic created, and continue to create, experiences of terror that can only be overcome by the heroine's knowledge and intelligence, advocating for women's education as a means to survive the gothic plots of their lives.

My study will link more recent feminist recuperations of the gothic to foundational conversations that still define and frame scholarly conversations about gender in the genre, notably Hume’s controversial 1969 essay in PMLA, “Gothic versus Romantic: A Revaluation of the Gothic Novel.” Hume famously created the distinction between horror and terror, categorizing male-authored gothic novels as works of horror and female-authored novels as works of terror. He then trivialized terror as "easy manipulation" and "drawn-out suspense" (285). He prioritized and valorized horror, dismissing women's gothic novels - and Radcliffe’s Mysteries of Udolpho, specifically - as less serious. Hume writes that, "Terror-Gothic works on the supposition that a reader who is repelled will close his mind (if not the book) to the sublime feelings which may be roused by the mixture of pleasure and pain induced by fear. HorrorGothic assumes that if events have psychological consistency, even within repulsive situations, the reader will find himself involved beyond recall” (285). Hume's article of course unleashed a firestorm of response and criticism, including Ellen Moers's response in Literary Women in 1976, which pushed back against this idea. In my thesis, I am working to redefine terror not as the lesser of two sensations, but to rethink the distinction, first, and second to recognize terror as a sustained experience that outlives momentary feelings of horror and impacts daily life, specifically for women.

With the recognition today of the terror inherent in being a woman, this is an ideal time to analyze the ways in which women writers of the gothic create and overcome terror in their novels. The link between gender and sensations of fear that were identified, at the beginning of 
the gothic genre, provide an interesting perspective to analyze how a respective author's gender influences her use of fear in the narrative. While male authors of the gothic often find fears in questions of illegitimacy, loss of familial lines, changing social and class systems, and foreign influence, women authors portray fears of married life and villainous husbands, the loss of their power and their ability to financially support themselves, and the daily dangers they face as powerless under male rule. For women in the gothic, education is their means of escape -knowledge allows women power in their situations and this power overcomes terror in the stories.

As opposed to sensations of horror, terror is not a "one and done" experience and is rooted in realistic possibility. In the gothic genre, I argue, scenes that create sensations of fear are terrible. I define terror, here, as a sustained feeling that lasts throughout the novel, a sensation that is maintained for both the reader and the protagonist. It is a driving force behind the protagonist's actions and inactions, keeping them alert to surrounding danger. Terror is an ongoing state of anxiety, coloring their moves and thoughts from then on, reminding them of the threats lurking and dangers around each corner. It is pervasive, enveloping, and suffocating. Terror is all-consuming, blood-curdling, and physically taxing. Diana Wallace, in The Female Gothic: New Directions (2009), writes “The Female Gothic, as the essays in this volume bear testimony, is shaped by many issues, including national identity, sexuality, language, race and history. It is also the case that the form challenges and complicates such issues and this is why it is of such major literary and cultural importance” (10). This sense of reality that comes with reading about the terror of powerlessness at the hands of the patriarchal system, the constant threat of bodily harm, violation, and devaluing, along with the knowledge that each woman is one family member's death away from destitution, in turn creates the experience of terror for the 
late eighteenth-century woman reader because of the unfortunate likelihood that these same circumstances could actually occur in that reader's real world. Terror in gothic works centralize an imprisoned heroine who is threatened by a tyrannical male figure, which explains the supernatural, while in contrast, horror in the gothic is "one of masculine transgression of social taboos, characterized by violent rape and/or murder, which tends to resist closure, frequently leaving the supernatural unexplained” (Wallace 3). Horror in the work consists of perverse depictions of human bodies, violent scenes of death, and dramatic confrontations; all these sensations, while evoking an emotional response, are momentary feelings that function as "shock value” in the novel. Grotesque depictions of death and rotting corpses, jump scares, and supernatural impossibilities all constitute horror, a momentary feeling that passes. Conversely, terror in the novel is created from fear of a woman's body rather than the grotesque mutilation of it. Further, as I find is key across the novels I analyze in this thesis, terror is a chain of cause and effect that actually begins with the fears of male characters and then is transmitted to the women: male characters fear birth and the power it gives women, they fear women’s education and intelligence, and they fear the potential role of educated women in society. Women writers of the gothic are particularly situated to understand and portray this cause and effect because of their marginalized position in patriarchal society. While there is a disparity between the marginalization of white, cis-gender women and all other women, they all suffer from the powerlessness that they are forced into because of their gender, making them sensitive to the complex structures of oppression and their consequences. Eugenia C. DeLamotte writes in Perils of the Night: A Feminist Study of Nineteenth-Century Gothic that "there is the suspicious fact that when terms like 'high Gothic' are used, they inevitably refer to a canon that is almost exclusively male, even though women were (and are) the primary readers, protagonists, and 
creators of the genre. Only recently has serious attention been called to what should have been a striking fact: most of these books are about women who just can't seem to get out of the house" (9-10). This is what gothic literature written by women reveals: the cycle of terror that women experience and suffer begins with men's fears of women's power, agency, and bodies. The fear that men in patriarchal societies experience from women that they have subjugated has led them to act out their terrors directly onto women and their bodies. Their terror of women resulted in them limiting, oppressing, and controlling women, socially, physically, and narratively.

\section{Education, Women's Roles, and Businesswomen in the Eighteenth and Nineteenth Centuries}

In addition to redefining aspects of the gothic, my thesis will expand on the idea of education as a defense from terror and will argue that women writers look to the gothic form as a kind of pedagogy; they examine how different types of women’s education -- domestic, scientific and medical, familial, experiential, cultural, and academic -- allow women to succeed in different life-threatening situations. Gothic literature has its basis in terror, horror, and marginalization created by situations of powerlessness at another's hands, which has created a space for women writers to represent the fear involved with living life as a woman. My thesis adds to an ongoing scholarly discussion about terror and horror by investigating instances of women’s education within gothic novels written by women authors. I will look to their narrative strategies as pedagogy, aware of and self-reflective about the unique challenges of teaching women readers how to cope with and survive the constant threats of their predatory cultures.

I will also establish the changing views of women's education in the eighteenth and nineteenth centuries. In addition to the primary texts in the coming chapters of my thesis, here I 
will read several works from the eighteenth and nineteenth centuries that discuss education from women's perspectives that provide insight into the changing cultural thoughts about women's rights to be educated. In order to better understand the three novels I will analyze in my chapters, here I will look at Mary Wollstonecraft's A Vindication of the Rights of Women (1792) which calls for girls to be taught alongside boys and on the same subjects. Maria Edgeworth’s "Practical Education” (1798) focuses on creating learning materials for both boys and girls that they can understand and that encourage them to engage with the world around them. In this work, Edgeworth “criticizes romances and recommends more sensible reading for women” and "exposes the narrative trope of female rivalry as over-determined and banal, and those 'informed' by such logic as gullible and irresponsible readers” (Johnson 14). In "Practical Education," Edgeworth notes that education should be enjoyable for children and should be similar in manner to experimental sciences. She highlights, too, that education is not a natural genius, but a taught one. Regarding women's education she writes that:

Women cannot foresee what may be the tastes of the individuals with whom they are to pass their lives. Their own tasks should not, therefore, be early decided; they should, if possible, be so educated that they may attain any talent in perfection which they may desire, or which their circumstances may render necessary...Mothers will look back, and observe how much the system of female education has altered within their own memory; and they will see, with "the prophetic eye of taste," what may probably be the fashion of another springanother race. (Edgeworth 382, 520) 
While Edgeworth's reasoning for women's education is less progressive than Wollstonecraft's in that she advocates for education to complement a woman's future husband, she is still advocating for a much wider range of study for women than they had been offered before. In contrast, Anna Laetitia Barbauld's Lessons for Children is a series of experimental pedagogical primers that emphasizes learning through the senses. The sublime in the gothic, similarly to Barbauld's philosophy, works to find a middle ground between uplifting the female spirit (representing genius), while still rendering the soul abject through conformity to masculine ideals and principles (Miles 54). I will acknowledge feminist readings of gothic works and the changing history of education in the eighteenth and nineteenth centuries that allow for a rethinking of how women's education is presented in gothic literature. Each woman author that I will analyze in my chapters advocates for a different type of education that correlates to the changing ideas of education in their time. The pedagogy in their novels teaches their women readers the value of this knowledge in their lives.

Some of the important changes in perspective of the eighteenth and nineteenth centuries that affected women's education were in the ideas of marriage as an institution and in the conception of gender. Chris Roulston notes that "the definition of marriage was undergoing an important paradigmatic shift" and that at the turn of the nineteenth century, readers "can begin to see the construction of a new ideology of domesticity and a concomitant destabilization of this ideology” (25). These questions of where women fit within the social structure also prompted questions about women's education, and many believed that if women were going to take equal part in society, they needed to be educated equally as well. Writing at the end of the nineteenth century, Karl Schaible, a German revolutionary and linguist published a critical essay "The state and education" in which he notes that: 
To remedy this neglect of female education, an agitation has commenced on the part of enlightened women and unprejudiced and philanthropic men in this country, as well as in France and Germany, the aim of which is the improvement of the education of women... In any reform of education the important question of the education of girls ought, therefore, not to be overlooked, and the State, if ever it does take upon itself the direction of the education of the country, is bound to establish schools of all grades; primary, secondary, and higher or special degrees, for girls as well as for boys. It is a strange circumstance that even the much decried Middle Ages were on this point in advance of us moderns, for in the girls' schools of this so-called dark age, which were attached to the nunneries, English girls were instructed not only in reading and writing, drawing, needlework and confectionery, but also in classics, science, and even in medicine and surgery. (Schaible 126-7)

Over a century after Wollstonecraft wrote Vindication, her ideas about equal and public education for both young boys and girls were reiterated by Schaible and viewed as less of an ideal situation and more of a necessity for the furthering of education. Like this essay, print played a large role in the debate about female education in the eighteenth and nineteenth centuries; with the mass production of the novel, both construction and subversion of gender roles were present in both public and private spheres and the gothic genre was specifically directed toward a female readership (Ellis x; Jennings v). While these novels were becoming increasingly popular among women, cultural authorities were adamant that "masculine” learning was not for young ladies and women were actively persuaded against both reading and writing 
through the pervasive 'misogynist bogey figure of the 'learned lady,' horrible, laughable, unwomanly, often unchaste,” who appears in all types of forms in literature of the time (Sandock 144). Not only did literary figures of villainized women work against women in their pursuit of authorship, but cultural perspectives of their relationships with other women worked to keep women isolated and oppressed.

Reflecting the debate about women's education, the types of education possessed and utilized by women in early gothic novels are often practical and domestic. Still, they provide a solution to female terror in the genre and, in the process, women authors advocate for the agency acquired through the education of women. One of the goals of my thesis is to further articulate that education is not limited to formal learning in a classroom or university and is instead referring to any type of learning situation that results in new knowledge, habits, or understanding. I am also not considering different topics of education as more important than others; for example, knowledge of domestic management is not any lesser than that of formal academic subjects. In the chapters that follow, I look at instances of domestic and spatial knowledge as well as social knowledge that is passed on through generations, including specific knowledge of female sexuality and reproduction in and before the nineteenth century. As the genre expanded throughout the years and women's education was beginning to change, the gothic became a space for educated women to write and develop a new genre as well as to portray educated and intelligent female characters. Gothic literature was a space for the new class of educated women to reach out and advocate for the education of other women. My thesis will trace that ongoing conversation, with a focus on how recent studies, and recent gothic novels like Silvia Moreno-Garcia’s Mexican Gothic (2020), take up but also resist the gendered distinctions between horror and terror, in relation to the role of women's education as one 
solution for surviving both that which is horrible and terrible in womanhood. Since the eighteenth century, the gothic has flourished in times of uncertainty and social change, mirroring the fears of its culture. It has been particularly adept at representing cultural fears of women's rights and of movements advocating for women's equal access to education.

\section{Female Precursors and the Success of Businesswomen}

In order to understand women writers of the gothic, I must first recognize the female authors prior to the inception of gothic literature who played a part in creating the genre and who set up frameworks that we see in the gothic novel after it is established as a marketable, popular genre. Authors like Aphra Behn and Eliza Haywood were well-known in their time and aspects of their stories set the stage for themes and tropes of gothic writing. Before the official beginning of the gothic genre with Horace Walpole's The Castle of Otranto (1764) and Clara Reeve's The Old English Baron (1777), a reworking of Walpole's original, there were several women writers who paved the way for the genre. Behn, writing in the late seventeenth century, was one of the first women to make her living as a writer; her inclusion of supernatural elements and female heroines in short novels like The History of the Nun (1689) is proto gothic. Here, Behn's main character Isabella is sent to become a nun at a very young age and as she matures, she meets and falls in love with Henault, who convinces her to run away with him. Eventually, their poverty forces him to go away to war, where he is reported dead and Isabella eventually remarries years later. In a move similar to Ann Radcliffe’s later fully explained supernatural occurrences, Henault miraculously returns from the dead as "a Man in a very odd Habit, and a worse Countenance” with "no Feature nor Part of Henault about him" and reveals that he has been held captive all these years (Behn). While Isabella is a resourceful and strong woman who commits a 
crime to save herself from being labeled a bigamist, in the patriarchal world of the seventeenth century she must take her punishment and die at the end of the story. With the purposeful erasure of early female writers from the literary canon, Behn's work was dismissed as minor or morally depraved by authors such as Sir Walter Scott, until the mid-twentieth century (Martin 585). Haywood, publishing prolifically in the 1730s (upwards of seventy works in her life), is today seen as one of the founders of the novel in English; she also wrote The Female Spectator, a monthly publication in which she discussed issues of marriage, reading, education, and conduct for a specifically female audience. In her amorous novels, chase scenes and suspenseful depictions of rape, such as in Fantomina (1725), anticipate the pursuit that becomes one of the defining features of the gothic.

However, Behn and Haywood were not the only women to find success in the literary world of the eighteenth century; around this time, the advances in transportation and the availability of jobs in the city of London resulted in a mass migration of women from the country. This migration of women looking for work created an unequal ratio of women to men. With the statistical un-likelihood of marriage for most of these women, they turned to their work, and with the development of the printing press and growing publishing market, they found their place in the literary world. Not only did women own shops and businesses, but they worked in the publishing industry and were an integral part of the literary culture of the eighteenth century. This vast number of independent and successful women triggered a campaign in the 1730s to get women to go home - led by periodical authors like Joseph Addison and Richard Steele. As male publications persuaded women readers to retreat to their homes and male readers to question female independence, and as the gender ratio shifted back, the literary achievements of late seventeenth- and early eighteenth-century women began to be forgotten. In particular, those 
works that pushed the boundaries began to disappear from collective memory; while novels of sensibility authored by women in the later eighteenth century were accepted and sometimes even promoted, those earlier novels by Behn and Haywood, which advocated for women's independence and education, were not being reprinted. Collections and anthologies, created by men, did not feature the women's works that had been so popular only a generation before. Many of the women's works of the early eighteenth century would not be recovered again until the digital preservation efforts of the early twenty-first century.

The gothic offered a new opportunity for women writers to continue the work of Behn and Haywood but within the accepted conventions of the novel of sensibility. After 1764 and Horace Walpole's publication of The Castle of Otranto, the next gothic work is Anna Laetitia Barbauld’s gothic fragment “Sir Bertram” that appears in her and her brother John Aikin’s essay “On the Pleasure Derived from Objects of Terror" in 1773. Following that, Clara Reeve published The Old English Baron (originally titled The Champion of Virtue) in 1777 as a response to Walpole's Otranto. Next, Sophia Lee's published The Recess in 1783, followed by the next piece of gothic written by a male author since Walpole with William Beckford's Vathek in 1786. After this, Ann Radcliffe begins her publishing career, and just eight years later Mysteries of Udolpho is released in 1794. The social and political climate of the time was ripe for women writers to immediately begin working in the gothic genre from its inception; with the beginning of Radcliffe's career in 1789, she would come to define gothic literature and become the highest paid author of her time, earning $£ 500$ for the publication rights to Mysteries of Udolpho. 


\section{The Gothic Genre and \#Metoo}

In the following chapters, I will analyze three gothic novels, from the eighteenth, nineteenth, and twenty-first centuries, to understand the ways in which women's access to different types of education helps them escape trauma and reason through terror; the types of education that women authors of the gothic advocate for evolve over time, from domestic/private to medical/scientific to cultural and academic, as women's rights and roles in society develop. I argue that female authors of gothic works portray educated women as strong and capable to advocate for women's pedagogy.

Before discussing women's education in these novels, I need to discuss and define who I am referring to when I say "women”. In the first two novels that I analyze, the authors are both middle class, white European women whose fears were based on their positionality in English society and wrote from a privileged perspective and as such, their intended audience would be those like them; when Radcliffe and Shelley advocate for the education of women, they are championing the white, cis-gender woman. Although the character of Safie in Shelley’s Frankenstein will work to push these boundaries a little, it would be irresponsible to claim that Shelley advocates for the education of all races, sexualities, and classes of women. In the first two chapters of my thesis, I will be specifically talking about white, middle class, cis-gender women's education and these are the same women that the authors will advocate for.

It is also important to keep in mind that living in the times and places that these women writers did, they would have been socialized to fear certain people, ideas, and values; they were both living in post-Revolutionary societies after the American and French Revolutions and as members of that society, would have been socialized to fear unstable, politically rife countries because of their immediate potential for war. As members of societies that also depended upon 
the slave trade as well as vastly wide merchant trading, these women would have been socialized to fear different colored bodies and "foreigners" as untrustworthy. As subjects of a highly patriarchal society, they would have also been socialized to fear the loss of their virtue and all threats to their reputation as well as the taboo subjects of women's private reproductive functions. When Radcliffe and Shelley write terror in their works, these socialized concerns are at the forefront of their stories.

Many of the basics of socialized fear stem from the same concerns: power, death, and physical harm. However, in looking at Mexican Gothic, a novel that was written over two hundred years after the inception of the gothic, these fears manifest in new and very different ways. For example, in early gothic works we see the fear of power manifest as anxiety about illegitimate rulers and about the oppression of women characters for the benefit of male authority; in Latin American works, though, this fear stems from colonization and subjugation to white and European persons. In the first two novels that I analyzed, I found fear located in women's ability to control and make decisions about their bodies and fear of those who do not look or act like the middle- and upper-class white Europeans who were writing. In the Latin American gothic, in contrast, characters fear white bodies; the power and oppression of colonization that Latin American countries experienced at the hands of invading Europeans flips the source of fear. Other sources of fear in Latin American countries stem from women's bodies, their agency, and their intelligence. Unlike Mysteries of Udolpho and Frankenstein, when I talk about women in the final chapter, I will be referencing a much different demographic; we are no longer limited to white, middle- and upper-class British women. Moreno-Garcia frames her gothic novel from the perspective that has historically been muted; her Mexican heroine is the type of woman who would only ever have been marginalized in gothic writing (similarly to the 
ways that the intelligent Safie was described in terms of her race and foreign religion and her "need" to convert to Christianity in order to live a full life).

In noting the socialization of fear in these women's lives, it is also important to discuss the effects of the hidden curriculum on their gothic novels. This theory supposes that "lessons of violence are often passed to students through the often-unnoticed knowledge developed through the hidden curriculum. The hidden curriculum can be as seemingly innocuous as what gendered line to stand in to go to the bathroom to deeper lessons about cis-gender ideals that arise when lines are split by gender” (Wozolek 273). The hidden curriculum can pass on ideas like what gender, success, and ways of being look like and in doing so, can normalize certain forms of violence and the hidden curriculum often found in literature works to uphold oppressive social structures. While these are rather new ideas, "Some feminist scholars are looking to the nineteenth century to understand today's cultural crisis of sexual violence and harassment, and they are using today's cultural vocabulary, cautiously and intentionally testing the promises and limits of strategic presentism to re-interpret fictional and historical narratives from the past” (Dalley 6-7). With this view in mind, we gain a new perspective on acts of sexual abuse and the threat of sexual violence in gothic works that were written in a time before these theories and ideas had been articulated and studied.

As I write today, with perspective after the \#MeToo movement, which has brought women's daily terror to public attention and is pushing for the systems that enable this terror to be dismantled, it is important to note how perceptions of women's experiences of terror have changed since the eighteenth and nineteenth centuries. The post \#Metoo perspective that I use in my work calls for a recognition of all women and the cycle of terror that they are subjected to by men who are afraid of their power and potential. As we can see, "This is a point of privilege- 
the privilege not to see how one's action can cause another feelings of terror. The expectations of the men, regardless of context, to be able to abuse a woman is an example of how the hidden curriculum of violence has operated within an assemblage” (Wozolek 281). We have begun to talk about the inherent dangers and daily fears that women face in a much more open and empathetic way. Instead of ignoring or disbelieving women who were afraid to leave their homes alone or who refused to be around men in certain contexts, we have now begun to realize openly as a culture that these fears are real and problematic. This modern perspective allows us to look back through literature to see that a woman in the nineteenth century also experienced the cycle of terror at the hands of men before they had the ability and methods to understand these structures.

There is criticism of the popularized use of the hashtag on social media and its availability for any and every one to use it. Some raise concerns that the movement "is ultimately gifting managers with a version of feminism that remains absolutely compatible with the subordination of the workforce to continuous and proliferating forms of assessment” (Cherniavsky). However, \#Metoo, as a widely accepted movement addressing the harassment of women, is useful in my analysis of gothic texts written by women. This wide acceptance of the cycle of terror that women continue to experience today allows a view of gothic works as expressions of this prolonged sensation of terror. The gothic genre has long been held as a vehicle to convey women's traumatizing experiences living in patriarchal societies that did not afford them agency. The ubiquity of haunting gothic metaphors and their meanings have been analyzed by feminist theory (Wallace 38). This theory, in the 1970s, used by authors like Moers, saw the popularity of gothic writings among women as the beginning of a new consciousness that allowed the female psyche expression. As I note in this introduction, however, this 
consciousness was not entirely new -- women of the nineteenth century may well have heard about the success of their female predecessors in the business and literary worlds of the early eighteenth century. It is possible that they could still view themselves as equal and participating members in the public sphere (Miles 43-44). With an understanding of women's positionality in the eighteenth to twentieth centuries, the post \#Metoo perspective that I will use in my thesis allows me to view the authors of the time as women with social awareness, and with understanding of their potential agency, and with historical reasons to have the confidence to make their way in the literary world. 


\section{CHAPTER II: A HOME EDUCATION: SPATIAL KNOWLEDGE AND TERROR IN ANN}

\section{RADCLIFFE'S MYSTERIES OF UDOLPHO}

Later gothic literature of the nineteenth century, like Frankenstein, The Strange Case of Dr. Jekyll and Mr. Hyde, and Dracula, embraced and critiqued science and experimentation as frameworks for their stories of terror and horror. In these novels, science is a demonstration of a characters' intelligence and problem-solving abilities but also a test of their morality. Though less frequently noted, this framework is also evident in the early gothic of the eighteenth century as well, though the "science" was not portrayed so directly and is often a more subtle reasoning process. Ann Radcliffe's The Mysteries of Udolpho (1794) sometimes gets a cursory glance when analyzing the influences of scientific knowledge and contemporary trends in women's education, such as by Ulrike Kristina Kohler, Adam Miller, and Anne Chandler. The first few chapters of the novel focus on Monsieur St. Aubert, his thoughts and beliefs about society, with only passing mention of the botanical as well as philosophical and literary education he passed on to his daughter, Emily St. Aubert. On the surface, Emily would seem not to be an intellectual or at all scientifically interested -- not much time is spent describing her education -- but the novel follows Emily as she navigates and conquers her fear of the unknown through an understated application of empiricism and experimentation. That this is played out in domestic surroundings connects the education she received from her father to the domestic, practical knowledges in which she, as a late eighteenth-century woman, would have been robustly educated. She proves to be highly skilled and intelligent in her maneuvering of the home space. By thinking of Emily's interactions with the interior of the castle as a problem-solving process that requires a range of skills, domestic but also scientific (in that she seeks to understand the causes of seemingly supernatural occurrences, for example), I show that not only is Emily 
intelligent and educated, which allows her to cope with her terrifying environment, but that Radcliffe seems to advocate for women's authority in their homes by means of knowledge of their space through examples of domestic education and situations of terror. In other words, domestic education is not uneducation - it is a legitimately intellectual means of survival. Knowledge of scientific causes is not antithetical to that domestic knowledge but productively complementary.

Radcliffe's Mysteries of Udolpho, which has come to be known as the archetypal gothic novel, was published in four volumes and follows Emily St. Aubert's travels from France to Italy with her aunt and new uncle, the villainous Montoni, to his gothic castle high in the mountains. Here Emily experiences several terrifying encounters that threaten her mental health and her safety until she eventually escapes and is reunited with her lover, Valancourt. Keeping in mind the space that Radcliffe inhabited in her own life, I examine Mysteries of Udolpho to find and analyze instances of women's education (note my clarification of women from the introduction) and how it is a solution to terror. I also work toward identifying what type of education Radcliffe herself advocated for through this novel. The idea of education presents itself early in the novel when we are introduced to the character of M. St. Aubert, an intellectual who passes along all his knowledge and his passion for study of languages, literature, and botany, among other fields, to his daughter Emily. While Emily’s intelligence mostly manifests itself through domestic and spatial knowledge in the novel, her quick wit and ability to think rationally are due to her father's vigorous education of her in her youth.

Radcliffe lived a solidly middle-class life. Though she only published five novels, she was widely popular and was the highest paid author of the 1790s, and she and her husband could 
afford to travel, unlike many families of the time. As a middle-class, white, cis-gender woman, Radcliffe wrote from that perspective and created characters of the same race, sexuality, and social standing; for the remainder of this work with Radcliffe, when I talk about women, I am specifically talking about these white, cis-gender, middle class women and their fears based on their positionalities in English society, unless specified otherwise. Radcliffe was writing in the 1790s, a time that was fraught with political upheaval. We can see the uncertainty of these politically rocky countries reflected in Radcliffe's portrayal of wild Italy, which is running amuck with banditti and robbers, and her villain Montoni is representative of the instability and crime of the time. Reflective of the world around her, we also see deeply socialized fears of women's lost virtue and the threat that men pose for women's social value. The terrors that we find in Radcliffe's works are all related to social standing, as Radcliffe was intimately involved in the precarious social structure that both worked against women and imprisoned them.

As I note in the introduction, as opposed to sensations of horror, terror is not a "one and done” experience and is rooted in realistic possibility. To talk about terror and education here, I argue, scenes that create sensations of fear are terrible. In my introduction, I defined terror as a sustained feeling that lasts throughout the novel, even between the frightening scenes. In a similar manner, I am defining education in a more general and realistic way; education is not limited to formal learning in a classroom or university and is instead referring to any type of learning situation that results in new knowledge, habits, or understanding. In my introduction, I established that I am not considering education in a hierarchy, assuming that knowledge of domestic management is a lesser form of education than the study of academic subjects. In Mysteries of Udolpho, I will look at instances of domestic and spatial knowledge; learning about the architecture, function, organization, and management of the domestic home space and polite 
social culture and learning about one's own position within that space, with consideration of one's relationship to the layout and networking of the buildings, where things are located, and where they lead. By reading closely from Radcliffe’s work, I am connecting domestic and spatial knowledge with Emily's ability to survive the sustained state of terror that she, as a middle-class cis-gender white woman of the revolutionary eighteenth century, must endure on a daily basis. It is important to note that because of her status and privilege, she has the power to navigate those spaces and to escape, though not without consequences.

Horror and terror are represented differently by male and female authors in the late eighteenth- and early nineteenth-century gothic. Radcliffe is often compared to her contemporary, Matthew Lewis, as the two represent the disparity between what I noted, in the introduction, has been posited as a binary gothic formula of women's terror and men's horror. Gothic written by English male writers in these decades focused on sexual violence, gore, death, and evil as “other”ness, whereas gothic narratives written by English women writers recreated terror in patriarchy, religious conventions, and the classist social structures of the time (Winter 90-91). In locating the sources of terror in their work, these women writers, including Radcliffe but also Charlotte Dacre and later, Elizabeth Gaskell and the Brönte sisters, provide a solution for overcoming or surviving these experiences- knowledge. Unlike some later gothic novels, Radcliffe's Mysteries of Udolpho portrays real, rather than supernatural, scenes of terror. Because of the scientifically empirical tools that her father had passed on to her, she is able to see the causes of what, in other novels, might have been supernatural moments. In a sense, her knowledge and ability to think through problems renders supernatural conventions unnecessary. 
The sensation of terror, then, is rooted in much more realistic experiences from women's lives. While the real life fears that inspire men's writing of the gothic are all horrific when read on the page, the fears in women's writing are all the more striking because, as Ellen Moers notes, “Radcliffe writes about the horrors of a woman’s life with a woman’s sense of decorum” (135). Moers's sentiment here from the mid-1970s still assumes that women writers were in some way obligated to portray themselves as "womanly," another aspect that was used to set apart the feminine terror from the masculine horror. While I disagree with Moers's choice of the word “decorum" as it implies an antiquated obedience to socially established etiquette and an expectation for how women could portray themselves, I think her recognition of Radcliffe's different approach to writing fear is important. This sense of reality that comes with reading about the terror of powerlessness at the hands of the patriarchal system creates the experience "other"ing of women in a patriarchal world that leaves them susceptible to everyday terror, and it establishes them as persons to be protected at the same time that it takes away all their agency and constantly threatens to ruin them at a moment's notice. In Radcliffe's work, just like in the gothic works by other women writers, terror comes from living in a world where evil is manmade, constantly threatening, and often realized (Winter, 99). In reading these gothic works, we most often see scenes of women trapped in the home, trapped in marriages, and trapped in society. Sandra M. Gilbert and Susan Gubar note in their groundbreaking work, The Madwoman in the Attic (1984) that, "Literally, women like Dickinson, Brönte, and Rossetti were imprisoned in their homes, their father's houses; indeed, almost all nineteenth-century women were in some sense imprisoned in men's houses. Figuratively, such women were, as we have seen, locked into male texts, texts from which they could escape only through ingenuity and indirection” (83). The 
terror that women of Radcliffe's time felt being under the thumb of men manifested itself into the well-known gothic castle that has become one of the cornerstones of the genre.

In Mysteries of Udolpho, Radcliffe delicately describes the difference between terror and horror throughout the work in the multiple experiences Emily has with terror as opposed to the momentary sensations of horror. Radcliffe explicitly includes a clear-cut example of this as she describes Emily’s discovery of the veiled picture in Udolpho:

a terror of this nature, as it occupies and expands the mind, and elevates it to high expectation, is purely sublime, and leads us, by a kind of fascination, to seek even the object from which we appear to shrink.

Emily passed on with faltering steps, and having paused a moment at the door, before she attempted to open it, she then hastily entered the chamber, and went towards the picture, which appeared to be enclosed in a frame of uncommon size, that hung in a dark part of the room. She paused again, and then, with a timid hand, lifted the veil; but instantly let it fall- perceiving that what it had concealed was no picture, and, before she could leave the chamber, she dropped senseless on the floor.

When she recovered her recollection, the remembrance of what she had seen had nearly deprived her of it a second time. She had scarcely strength to remove from the room, and regain her own; and, when arrived there, wanted courage to remain alone. Horror occupied her mind, and excluded, for a time, all sense of past, and dread of future misfortune. (Radcliffe, 248, 249) 
Here she describes the terror that Emily experiences as all encompassing, a wide view in which one experiences the sublime realization of the whole of temporality and elevates one to an omniscient position, while horror distracts one from this sublimity by forcing a recognition of the moment and sending one back to a more narrow focus. Emily experiences the sense of terror as she is aware of her circumstances in the castle, the mystery of the late Signora Laurentini who disappeared from the castle, and the anxiety that Annette experiences in relating that tale to Emily, all combined with the mystery of the veil. However, this broad suffering brought about by terror is eclipsed when she lifts the veil - curious about discovering what is behind it -- to view what is hidden; a wax figure that she mistakes for a dead body. The image overwhelms any of the sublimity she had previously been aware of- instead, she is so overcome that she loses consciousness. All the sources of fear in Radcliffe's work create feelings of terror with which the everyday nineteenth-century woman would be intimately familiar. Women faced a daily threat of being violated or abused from the very same men who created the parameters of her value in society.

\section{The Role of Education in Preventing and/or Coping with Terror}

It is a disservice to early women writers of the gothic to compare them to Mary Shelley’s experimental science narrative; not every female author of gothic stories was as radical and openly progressive as the author of Frankenstein, and to look for similar instances of education and scientific discovery in other authors' works often means overlooking the subtle ways in which these women authors did advocate for educated women. Mysteries of Udolpho is, in fact, a rich source of examples of women's practical education. Radcliffe’s characters place a lot of 
value on education, and many of the frivolous women characters are set against the protagonist, Emily.

When she first arrives in Italy, Emily hopes that she has found a companion in Signora Livona, a young woman who later visits Castle Udolpho. As Emily is pondering her situation trapped in her room:

a peal of laughter rose from the terrace, and, on going to the casement, she saw, with inexpressible surprise, three ladies, dressed in the gala habit of Venice, waling with several gentlemen below... one of the strangers looking up, she perceived the features of Signora Livona, with whose manners she had been so much charmed... This discovery occasioned her an emotion of doubtful joy... yet there was something so extraordinary in her being at this castle, circumstanced as it now was, and evidently, by the gaiety of her air, with her own consent, that a very painful surmise aroused, concerning her character. (382)

While Emily first believes Signora Livona to be an upstanding woman, her introduction is made by Montoni, and she later finds that women that Montoni believe to be distinguished have very different standards and morals than Emily. The morning after the party, Annette reports that not only did the Signors drink to excess all night, but so did Signora Livona (389). Here Radcliffe sets Emily apart from another young, distinguished woman by showing Signora Livona’s frivolous judgement of character when she arrives to party with Montoni, whereas Emily is searching for a way to escape from the same place. 
Similarly, Emily’s only other surviving female relative besides Madame Cheron is Madame Quesnel, who they visit in Venice. While she is hoping to find some news of her love, Valancourt, she soon realizes that Madame Quesnel's priorities lie elsewhere:

Madame Quesnel, who, when she was in France, had talked with rapture of Italy, now, that she was in Italy, talked with equal praise of France, and endeavoured to excite the wonder and the envy of her auditors by accounts of places, which they had not been happy enough to see. In these descriptions she not only imposed upon them, but upon herself, for she never thought a present pleasure equal to one, that was passed; and thus the delicious climate, the fragrant orangeries and all the luxuries, which surrounded her, slept unnoticed, while her fancy wandered over the distant scenes of a northern country. (211-212)

Emily, who has been forcefully removed from her home and her love, is looking for companionship and news of home, but Madame Quesnel only seems to be concerned with inspiring jealously of her travels. Or, perhaps, she is trying to assert her own version of education - being well traveled. This boasting about her experience and knowledge, however, is presented as social incorrect interaction. Focused only on what she has learned about the world, she is unable to appreciate her present circumstances, always looking forward to her next adventure. While Emily appreciates how beautiful Venice is and is able to take comfort in the sublimity of nature as her father taught her, Madame Quesnel appears vain and unappreciative in comparison. In this way, Radcliffe juxtaposes two very different attitudes toward setting to subtly advocate for a version of women's education that allows them to appreciate the domestic space in which they must reside. Madame Quesnel misses what there is to learn in her present interior and does 
not explore, while Emily is constantly curious, often leaving the safety of her room to investigate the mysteries of the castle. She is always learning new information about her situation and using her knowledge to facilitate her survival.

The issue of women's education in the eighteenth and nineteenth centuries is a complex subject to discuss, especially for women writers who were looked down upon for their attempts to participate in the masculine world of authorship. In fact, understanding what Gilbert and Gubar define as "anxiety of authorship- a radical fear that she cannot create, that because she can never become a 'precursor' the act of writing will isolate or destroy her” (48-49), we can see issues like the education of women in the "evasions and concealments of their arts" (74-75), issues that are not addressed on the surface level but masked in their writing so as to not be obvious. They provide another reason for male authors to ridicule or attack them. Of course in the early 1980s, Gilbert and Gubar were not yet aware of the catalogue of works created before Radcliffe, as they had been systematically erased from literary anthologies and collections created by men and taught in educational systems created by and for men. As I discussed in my introduction, authors like Aphra Behn and Eliza Haywood had been successfully published authors before Radcliffe's time and were precursors of the gothic novel, but women as recently as 1984 were prevented from learning about these women because patriarchal education systems did not care to teach women's history. While we can see the holes in Gilbert and Gubar's work from our current perspective, their idea about of the “evasions and concealments” of women’s writing becomes much more meaningful when we take into account the vast history of women's writing. Not only were their writings purposefully excluded from the literary canon and study, but the deeper ideas in their works aimed at their female audience were part of a much bigger conversation of women over centuries of writing. This use of concealment in their writing invites 
a deeper reading of their work to try to look past what they create on the surface for men to what they have to say to women below that.

Hidden within the narrative of Mysteries of Udolpho is Emily's proclivity for study, for science like botany and galvanism, and for intelligent discussion. These instances are often only briefly mentioned and always overshadowed by something else in the plot so that upon first reading, one could entirely miss them. In the introduction to the St. Aubert family, Radcliffe's first mention of Emily is to describe her room and through that, describe her personality, priorities, and inclinations. Adjoining the greenhouse, "was a room, which Emily called hers, and which contained her books, her drawings, her musical instruments, with some favourite birds and plants. Here she usually exercised herself in elegant arts, cultivated only because they were congenial to her taste, and in which native genius, assisted by the instructions of Monsieur and Madame St. Aubert, made her an early proficient” (3). This quick description that is easily overlooked also functions as our introduction to Emily, and its focus on her intellectual prowess and interests are front in center in the definition of her character. While perhaps the subjects of literature, drawing, and music were not inherently scientific, Radcliffe specifically notes that she only studies them because she wanted to and that she was instructed by both her father and mother. Education, it seems, it not only a priority for Monsieur St. Aubert but for his wife and daughter as well, and they are all highly educated, practiced, and curious. This subtle tying of Emily's character with intelligence and academic study from the very beginning allows Radcliffe to present her ideal woman: one who is not only educated but enjoys and seeks out her education. This brief mention is quickly forgotten as Radcliffe moves on to set the stage for her story. Similarly, Emily engages with science in a scene that is easily overshadowed by the frightening circumstances surrounding it. As she is being smuggled out of Udolpho by Montoni's henchmen 
into a coming electrical storm, she again notices a flame that she had seen moving about the ramparts which "appeared and disappeared frequently" (373). In her first experience of this flame, she asks a soldier “what is that tapering light you bear?' said Emily, 'see how it darts upwards- and now it vanishes!'” (373) to which he replies that the flame has been appearing on his sword all night long and he cannot fathom what it means and even suggests that it has supernatural origins. As she’s leaving the castle with Montoni's men, she notices the same flame on their swords and one mentions that "I have often seen it before a thunder storm, it is an omen of that, and one is coming now, sure enough" (408) and immediately, Emily is relieved from superstition as she is able to make the connection between the coming electrical storm and the phenomenon she is witnessing without explicit explanation. While this supernatural scene perhaps required Radcliffe's readers to look into her citation of Pierre Bertholon to understand the working of electricity, Emily seems to immediately understand the significance of the vague information she is given. Whether this signals her previous study of experimental science or just her exceeding intelligence, she seems to have a better grasp on what she is seeing than any of her other castle-mates.

While it may have been a noteworthy instance to contemporary readers, Emily was not the only woman in the eighteenth century subtly engaging with education and cutting-edge scientific studies. Around the turn of the nineteenth century, scientific study and the understanding of science itself was evolving and beginning to take on distinct qualities; Radcliffe herself includes a footnote to explain the event mentioned above where a soldier's lance acts as a sort of lightning rod, conducting electricity and appearing to have a flame "tapering at its point" (408). In the footnote, she simply directs the reader to "See the Abbé Berthelon on Electricity" (408). Adam Miller explains that, 
Pierre Bertholon was a French scientist best known for his work on what would now be called Galvinism — the behaviour of electrical current when passed through organic bodies. For this footnote, however, Radcliffe probably has in mind Bertholon's treatise on electricity and meteorological phenomena, De L'Electricite des meteores (1787). In that text, Bertholon collects eyewitness accounts of unusual atmospheric conditions ranging from Saint Elmo’s Fire to tornadoes. Not surprisingly, these accounts are marked by superstitious bewilderment, which Bertholon attempts to explain via experimental methods. At a functional level, Bertholon works as an authoritative citation. His expertise justifies the apparently outlandish explanation of the glowing lance. (Miller, 537)

This combination of early scientific discovery and superstition works well in Radcliffe's work where she presents an often shocking and terrifying event and then later can rationally explain what happened. This case functions to show the way that knowledge, for Radcliffe, can dispel fear if one is privy to it.

Radcliffe's work is an early example in popular fiction of scientific experimentation and the home life mixing; in fact, many scientists of the time still experimented at home, and this allowed for an area of scientific study that was readily accessible to women (Hansen 56). As science was beginning to be practiced in the home space, which is where women were being educated, it began to mix with the domestic curriculum in the nineteenth century. Caroline Herschel, a female astronomer, Mary Somerville, a female mathematician and physician, Maria Edgeworth, a female educationalist, and Frances Burney, a female diarist and novelist, all studied and experimented from home (55). Similarly, botany was by far the most widely 
acceptable field of study for women as it allowed them fresh air alongside their knowledge (57). Women may not have been able to call themselves "scientists" outside of their house, but they were certainly becoming as well educated in it as men.

Scientific discovery and experimentation in the home space are mentioned casually in the beginning of Mysteries of Udolpho, where M. St. Aubert occupies himself with "botanizing” in the beautiful French countryside (8). Not only does the novel open with his life and his passion for learning and living outside of society, but the principles and morals he passes on to Emily build the backbone of her outlook throughout the novel. He raises her to believe that, “'A wellinformed mind... is the best security against the contagion of folly and of vice. The vacant mind is ever on the watch for relief, and ready to plunge into error, to escape from the languor of idleness. Store it with ideas, teach it the pleasure of thinking'” (Radcliffe, 6). While his philosophy is in one sense liberating, his opinion of educated persons also subtly discriminates -he is most concerned with security and protection from one's self and education as a cure for internal sin and laziness. As a white, middle-class man, he passes along these principles to Emily, for he cannot imagine her need for security from external forces that she will face in her daily life as a woman. For him, it is of the upmost importance that Emily learn to protect herself from herself, as he has never been socialized to fear outside forces; perhaps this masculine education that he passes down to Emily in part allows her to remain rational (i.e. in control of her internal conflicts) in the face of the many terrors she experiences later in the novel, Certainly, Radcliffe's choice here, in this paternal philosophy, seems to support an idea that a man has taught Emily how to control herself, thus allowing her to survive these events. Yet, Radcliffe also stresses that Emily has "native intelligence," and that the father - and the mother - had merely "assisted" her (3). Further, the education that Emily has received takes place outside of 
the home, which was common and socially acceptable for women in the time and yet, the topics that M. St. Aubert is teaching her would have caused an eighteenth- or nineteenth-century reader to pause. Ulrike Kristina Kohler's work is relevant here: Kohler notes that, “unlike most of her contemporaries, Radcliffe's 'model fathers' carry out the instruction of their daughters without worrying whether too much learning might turn a girl into a frightful bluestocking destined to die a lonely spinster as, according to general opinion, no man in his right mind would ever be tempted to marry such a woman” (107). While he may not be able to imagine the threatening situations that she will someday need that education for, St. Aubert is more concerned with Emily's enjoyment than with what is "proper" for her to read and learn:

St. Aubert cultivated her understanding with the most scrupulous care. He gave her a general view of the sciences, and an exact acquaintance with every part of elegant literature. He taught her Latin and English, chiefly that she might understand the sublimity of their best poets. She discovered in her early years a taste for works of genius; and it was St. Aubert's principle, as well as his inclination, to promote every innocent means of happiness. (Radcliffe 6)

It is important to note here that in her creation of the ideal father figure, Radcliffe writes a man who takes great care in the education of his daughter and goes above and beyond what is socially acceptable for her to not only learn, but enjoy. After M. St. Aubert's death, Emily is by far the most academically educated character in the novel and is only matched by her lover, Valencourt, who does not appear to have any knowledge or passions of his own but only touches on topics that Emily already knows and loves. 
Education is a quality in Radcliffe's characters that sets them apart from each other; the highly educated and intelligent Emily is clearly set at odds with her Aunt Madame Cheron, who is quickly characterized as vain and content in her undereducated life. At the end of M. St. Aubert's life, he places Emily in Madame Cheron's care and tells Emily that, "she is not exactly the person, to whom I would have committed my Emily, but I had no alternative, and I believe her to be upon the whole- a good kind of woman” (Radcliffe 81). His estimation proves to be true if a little bit understated. Immediately upon receiving Emily, Madame Cheron’s seeming ignorance of social decorum and her self-importance are evident and set her at odds with the intelligent and considerate Emily. Once Emily has been forced to leave the country with the now Madame Montoni and her new husband, Emily finds herself in several scandalous situations that her aunt ignores or blames on Emily herself. The severity of the situation escalates when the family flees to Castle Udolpho, located in the mountains of Italy. Trapped and isolated, Emily immediately recognizes the precariousness of the situation and has only her aunt on her side. However, "though misfortune had somewhat conquered the asperities of Madame Montoni’s temper, and, by degree for others, the capricious love of rule, which nature had planted and habit had nourished in her heart, was not subdued. She could not now deny herself the gratification of tyrannizing over the innocent and helpless Emily, by attempting to ridicule the taste she could not feel” (Radcliffe, 243). Here we see where Gilbert and Gubar describe that "the images of 'angel' and 'monster' have been so ubiquitous throughout literature by men that they have also pervaded women's writing to such an extent that few women have definitely 'killed' either figure” (17). These categories of women that men created were so common in writing that they found their way into women's writing as well, and we clearly see that limitation here where Radcliffe plays into the trope of pitting women against each other. 
However, for an author who creates such a purposeful novel and utilizes subtle and hidden narratives to advocate for women's education, this demonizing of a woman, in the form of Madame Cheron, seems like a missed opportunity. Perhaps by showcasing the differences between these two women, Radcliffe is advocating for strong women who do not aspire to power. Emily never purposefully tries to run or own an estate, she never holds her status over others, and she never mistreats others of lesser ranks. However, the power-hungry Montoni is himself already at odds with Emily, and Madame Cheron does not add much to this conversation. And while Emily never aspires for social power, she does fight to choose the man she will marry and agency over her life, similar to what Madame Cheron has done in hers. Is it thus possible, in a provocative line of thinking, that Madame Cheron is a representation of the systemic oppression of patriarchy that weaponizes her against other women to simultaneously withhold those other women from power while keeping powerful women themselves within patriarchal rule? While Madame Cheron does terrorize Emily and proves to be an unfit guardian, she also holds a shocking amount of power and agency in the novel. Instead of cowering or fleeing from Montoni, she fights back against him and does not sign her property away to him until she dies, and it passes to Emily. It seems much more likely that Madame Cheron is a powerful woman who is working within the patriarchal structure that she finds herself trapped in; this structure unfortunately does not allow for powerful women to work together to achieve their goals. In order for Madame Cheron to get what she wants, she must see an enemy in Emily, who by all outward appearances is the "angel" woman.

The comparison between Emily's robust education and knowledge of social skills with her aunt is clear-cut and plays into how each woman conducts herself when they arrive at Castle Udolpho. Whereas Madame Cheron fights with Montoni, bringing about her eventual death, 
Emily's rational demeanor and clear-thinking time and time again center her and allow her to see beyond the terrifying events to understand the reason behind them. Differences in domestic education not only work to set characters apart from each other, but those who have been educated and are intelligent find that knowledge is power over terror. Emily's father raised her to not be swept away by sensation, and when she finds herself in the terrifying gothic castle, this education not only keeps her grounded but allows her to find her way out of the situation and escape to safety. Through the different portrayals of these women, Radcliffe subtly advocates for the education of a particular kind of woman and demonstrates how patriarchal social structure works to set powerful women against each other which, in turn, allows the structure to continue its authority and disables women from joining forces against it.

\section{Knowledge of Space as Power}

One of the most easily recognizable features of gothic writing is the gothic castle, which became a staple of the genre almost immediately. While there is a lot to say about physical space, location, and architecture and how they function in gothic works, I want to focus on what the knowledge of these spaces gives to the female characters trapped within them. In the eighteenth and nineteenth centuries, the home was part of the domestic sphere and as such was part of a woman's world. After their wild success in business and the arts in the eighteenth century that I discussed in my introduction, the rhetoric of the nineteenth century worked to create separate private and public spheres and regulate women to the private sphere as wives and mothers and more often than not they were not welcome in the public sphere of the nineteenth century; the domestic sphere, though, was her domain to rule as she saw fit (or more accurately, 
how she saw fit within the expectations of her father or husband). Women had more agency in their own homes, and these spaces offered them a safe space where they did not need to be as worried about their reputation, propriety, or being vulnerable to other men. Interestingly, however, one of the common features of gothic texts written by women is that the home is not a refuge to return to but instead is a prison in which they are trapped. While society painted the domestic sphere as the woman's sphere, even within the home women found that they did not have the agency they expected. Unfortunately, instead of the freedom to run a household, in their marriages they instead found new rules to follow and expectations to uphold. Diana Wallace explains that "the 'house' here (like the Gothic castle of later texts) is not just the domestic space, but itself a metaphor for the legal institutions of marriage and patrilineal inheritance (enacted through the 'bed') which erase the female name” (29). Supernatural and dramatic events often help to shadow domestic oppression and the lack of agency and authority that women hold in these gothic castles. In fact, some of the actions of the female characters would not have been appropriate outside of the gothic setting. In her work Social Reform in Gothic Writing: Fantastic Forms of Change, 1764-1834, Ellen Malenas Ledoux argues that space in the gothic supports alternative visions of the future, where women have power over their spaces, and those spaces become sites of agency for female characters (57). Though threatening and prison-like, the castle opens new possibilities for acceptable actions and methods of escape. Whereas male authors use gothic spaces to recall the "good old days" to present a sentimentalized past in which they had unquestioned power, women work within the space to create new possibilities and futures for their agency and authority.

By analyzing the way that knowledge of space functions in the novel, I illuminate how Radcliffe advocates for women's authority in their own homes. She portrays Emily as one of the 
only sensible characters inside of Udolpho; Emily's loyalty and responsibility set her on the journey with her aunt and new uncle, Montoni, to Italy and finally into the forests to Castle Udolpho. When Montoni is found to be fortuneless, his con to steal Madame Cheron's properties from her before she dies and they pass on to Emily, is revealed. Already, Radcliffe sets Emily up as the rightful owner of these properties and therefore as a figure with authority as an heiress. She contrasts that with Montoni, who is living in the run-down Udolpho, completely broke, and who has turned to highway robbery to regain his wealth. Montoni has taken power and authority over Udolpho by force when in reality, Emily is the only property owner present. This of course would be unusual outside of the gothic context; her nearest male relative, Montoni, would of course take over Emily's properties, but his villainy and trickery in the gothic world complicate this. Although he is the closest male relative, he is an illegitimate ruler and any of the male gothic writings would very clearly state that his power was not earned. In male gothic novels like Horace Walpole's The Castle of Otranto, the castle would need to be returned to its rightful owner. What Radcliffe does, however, is make the rightful owner a young woman. Here though, Emily cannot give up her rightfully inherited land to Montoni, the usurper and illegitimate authority figure. This complicated scenario in the gothic context allows Radcliffe to subtly set Emily up as the rightful authority figure while still working within a well-established male tradition of fears of illegitimacy.

One of the most important aspects of education for women in the novel is their learning and knowledge of their surroundings and their options for safe spaces. Not only do these gothic spaces help create alternative futures for women where they have agency and authority in their space, but it is their knowledge of these spaces that manifests their power. Living in Udolpho, Emily struggles to find her way around the maze-like castle and only feels truly safe with 
Annette and inside her bedroom. The sense of fear cultivated in these typically female-dominated home spaces highlights the daily terror of women's lives, even in domestic spaces. Udolpho is the classic, maze-like gothic castle, and Emily's ignorance of the layout and contents of its rooms leaves her in a state of powerlessness. She only feels confident and safe in the confines of her own room, even with the secret, unlockable passage that it contains. She knows where the entrances and exits are in her room and even though there is a mysterious passageway that cannot be locked from her side (she cannot lock anyone out but can be locked in), her awareness of the situation makes it less terrifying and something that she can anticipate and control. Annette, with her knowledge of the servant passageways, is another safe space for Emily; she trusts Annette to guide her through the maze to either her own bedroom or Annette's where they can put a door between themselves and the dangers without. Unlike Madame Cheron, who is pitted against Emily, Annette provides a female collaborator, a sister force through which she can feel secure and from whom there is no competition since Annette is "just" from the servant class. It is only when Emily is lost in the corridors that she experiences powerlessness and terror. After she has returned from Tuscany, she awaits Annette to guide her back to her room when she hears Verezzi and Bertolini ask Montoni whether she is back in the castle. Afraid of what these men will do if they find her, she attempts to flee down the dark hallway when the men run up the stairs and notice her. They move to chase her and Bertolini trips, extinguishing the only lantern, plunging them into darkness. Emily debates with herself, "whither to go, or how further to find her way in the dark, she knew not; she was aware only that she must not seek her apartment, for there she would certainly be sought, and her danger increased every instant, while she remained near it” (Radcliffe, 431). Emily knows that her only chance of regaining power over Verezzi is to return to Annette's bedroom, a space that no one else knows to look for her and where Annette 
has full knowledge and power over the space. Here Radcliffe highlights Emily’s intelligence and quick thinking; if she had run for her rooms, she would have surely been caught for that is the only place where Verezzi knows to look for her. Instead, she cleverly tries to find her way to the servants' quarters, her knowledge overcoming the situation that could very likely have ended in violation and ruin.

While Radcliffe subtly sets the scene for an authoritative woman landowner, she also highlights the differences between unknown, “dangerous” spaces and known, "safe” spaces. The best examples of this are of course the chase scene where Emily flees for safety from Verezzi. Radcliffe's description of the chase through the dark maze of the castle paints a clear picture of the power of knowledge of a space; she writes:

But, long before she reached [the hall's] extremity, the light, which Verezzi carried, flashed upon the walls; both appeared, and, instantly perceiving Emily, pursued her. At this moment, Bertolini, whose steps, though swift, were not steady, and whose impatience overcame what little caution he had hitherto used, stumbled, and fell at length. The lamp fell with him, and was presently expiring on the floor; but Verezzi, regardless of saving it, seized the advantage this accident gave him over his rival, and followed Emily, to whom, however, the light had shown one of the passages that branched from the gallery, and she instantly turned into it. Verezzi could just discern the way she had taken, and this he pursued; but the sound of her steps soon sunk in distance, while he, less acquainted with the passage, was obliged to proceed through the dark, with caution, lest he should fall down a flight of steps, such as in this extensive old 
castle frequently terminated an avenue. This passage at length brought Emily to the corridor, into which her own chamber opened, and, not hearing any footstep, she paused to take breath, and consider what was the safest design to be adopted. She had followed this passage, merely because it was the first that appeared, and now that she had reached the end of it, was as perplexed as before. (Radcliffe 431-432)

The terror in this scene comes not only from the threat of violation, but also from the unknown spaces surrounding Emily; if she knew the layout of the castle, she would know how to escape this threat and find safety in Annette's room. However, she does not know where she is, what doors lead where, and which direction she needs to go to get back into familiar territory. Radcliffe sets the scene with all the ingredients of womanly terror: aggressive men pursuing the heroine, darkness, and an unknown location. Not only is Emily lost in the castle, but she is plunged into darkness and not able to rely on her vision and intellect to guide her; instead, she is left to feel her way to safety as quickly and quietly as possible and her lack of knowledge of the layout of the castle greatly hinders her. She has a goal in mind for where she can find sanctuary but no idea how to get there; this, I argue, is the source of the most terror and anxiety in the scene. It is not enough to be chased through darkness with the threat of ruin but the unknown space itself functions to make the task appear impossible and entirely based on luck rather than ability. After spending so much time anxiously following Emily through the dark corridors, the power of knowledge of spaces is further evidenced when she finally recognizes where she is in the castle and begins to move away from her chambers and toward Annette's. 
It is interesting to note in this scene the high level of reasoning that Emily possesses in a moment of pure terror. Although she is fleeing for her safety and possibly her life, she is still able to think rationally and make decisions that keep her safe. Radcliffe writes that:

She was still breathing with difficulty, and resting at the end of the passage, when she heard a rustling sound, and then a low voice, so very near her, that is seemed close to her ear; but she had presence of mind to check her emotions, and to remain quite still; in the next moment, she perceived it to be the voice of Verezzi, who did not appear to know, that she was there, but to have spoken to himself...he turned to the right, and proceeded, with the same stealing steps, toward Emily's apartment, apparently forgetting, that, in darkness, she could easily elude his search, even in her chamber; and, like an intoxicated person, he followed pertinaciously the one idea, that had possessed his imagination...She now glided into a passage, that opened on the left, without, as she thought, being perceived. (Radcliffe, 431-432, emphasis my own)

While Emily is lost in the darkness of the castle, she still has her wits about her; although she cannot find her way to safety, she has the presence of mind to not cry out and draw attention to herself, leaving Verezzi without a clue to where she could be. The sharpness of her mind is literally able to overcome the terror of the situation and keep her hidden from her assailant. Radcliffe notes that lost in the castle in the dark, both Verezzi and Emily are on equal footing; even in the familiar space of her chamber, in the dark Emily would be able to elude his search. Not only this, but the tension of the moment affects Verezzi much more than it does Emily. While she can keep her mind clear, he acts like an intoxicated person and continues with his 
original plan even after the situation has changed. While Emily thinks rationally, Verezzi is drunk enough to "apparently" forget that even if he found her room, without light he would not be able to find her. This situation not only highlights the power that knowing a location has, but it shows that natural intelligence and an educated mind help cope with terror and set those apart from others who do not have presence of mind to overcome the terror they feel.

This chase through a dark and terrifying castle is an important part of the gothic genre, and yet the scene that Radcliffe creates focused on female terror is very different from the first gothic chase scene in Walpole's Castle of Otranto. Considered the first gothic novel, it focuses on Manfred, the illegitimate ruler of Otranto, and his scheming to bind his familial line with that of the legitimate ruling family through the marriage of the young Isabella to either his son, or upon his son's death, to himself. While this novel is written by a man and focuses most of the plot on the male characters and overturning illegitimacy, there is a scene told from Isabella's point of view while she is fleeing through the bowels of the castle away from Manfred. Unlike Emily, Isabella knows exactly where she is going and what she is looking for to find her freedom. She knows about the secret subterraneous passage that connects the vaults to the church and she knows that if she can get to the passage before Manfred, she will be safe in a holy place. There is a brief flash of terror when she sees a person hide behind the door that she needs to enter to find safety; but this is immediately overcome by her knowledge that she is beloved in the castle and that the secret passage is her only means of escape. Even though she does not know who is waiting behind the door, her knowledge of the layout motivates her to enter anyway; terror cannot stop her when she knows her freedom lies beyond the door. The stranger behind the door immediately agrees to help her find the piece of brass enclosed in stone that "is the lock, which opens with a spring, of which I know the secret. If I can find that, I may escape” 
(Walpole, 27-28). Not only does she know her location which allows her to overcome the terror of the chase, she also knows the secret of the trap door. Her knowledge is here highlighted for without it, there would be no way for her to escape.

While many elements of these scenes are similar, the biggest difference is Isabella's knowledge of her location; whereas Radcliffe creates terror in not knowing, Walpole's Isabella knows exactly where she needs to go to find safety, it is just a matter of beating Manfred there. In fact, Isabella's knowledge of her space allows her agency to create an escape plan and execute it, finding herself in a safe place. The terror instead is based in the threat of violence, not in Isabella's lack of knowledge. Her knowledge of her surroundings and of the layout of her home literally saved her from violation and from being forced into marriage.

After looking at how Walpole's Isabella navigates through the depths of the castle, we can see how a few decades later Radcliffe’s deliberate creation of an "unknowable,” maze-like castle works to create fear. By establishing Emily as the rightful (and legitimate!) authority figure, her lack of knowledge of the space is literally her authority over her property being stripped away from her. Montoni's plot to take her rightfully inherited property from her is in fact a plot to leave her powerless, susceptible to terror in everyday life with no safe, known space where she has authority and agency. While domestic spaces are places of imprisonment for women in gothic works, they also offer freedom and agency within their walls that women could not find outside. Moers writes that, “indoors, inside Mrs. Radcliffe’s castles, her heroines can scuttle miles along corridors, descend into dungeons, and explore secret chambers without a chaperone, because the Gothic castle, however much in ruins, is still an indoor and therefore freely female space. In Mrs. Radcliffe’s hands, the Gothic novel became a feminine substitute for 
the picaresque, where heroines could enjoy all the adventures and alarms that masculine heroes had long experienced, far from home, in fiction” (126). By creating a dangerous, and yet feminine space in her gothic castles, Radcliffe can advocate for women's authority in their homes and demonstrates that their knowledge of these domestic spaces gives them power and agency in their situations. No matter what terror they might face from men or society, if they have knowledge of their home and surroundings, they can find a way to escape, find safety, and correct the patriarchal tyranny of the gothic plot.

\section{Conclusion}

I have noted other instances of knowledge and education in Radcliffe's novel besides spatial knowledge that work to support the reading of Emily St. Aubert as a woman of intelligence and authority. Her unusually robust education provided by her father, combined with her fluency in social situations, sets her in opposition with her aunt, Madame Cheron, who is self-important, socially uneducated, and unhelpful. The differences in these women is a subtle way to advocate for the education of women outside of the structures of the patriarchal system; without Emily’s masculine education, Madame Cheron falls into the trap of playing within the bounds of society to get what she wants, which pits her against the "angelic" Emily. Emily’s education allows her to fortify herself without requiring the downfall of other women, and this allows her moments of rationality where she can overcome terror and find agency in her situation. Radcliffe's writing of womanly terror pushes back against the unfair social structures of her time and finds fear in the powerlessness of patriarchal ruling systems. 
The gothic castle is one of the most easily recognizable features of the genre and both male and female authors use it to help create the atmosphere of terror or horror that they are trying to convey. Where most analyses focus on the gothic castle as a place of imprisonment for women, I have read a few instances in Ann Radcliffe's Mysteries of Udolpho that show gothic spaces providing women with the power and opportunity to do things that they would not be able to elsewhere. While most women of the time would not be viewed as rightful property owners, placing Emily St. Aubert in the gothic castle with the evil Montoni allows Radcliffe to subtly claim Emily's right to her property and authority by playing on male fears of illegitimacy. Not only does the gothic castle allow Emily authority and power over her own estate, but Emily is allowed power over her situations and the agency to protect herself within her known spaces in the castle. Even though her bedroom contains a mysterious passageway that she cannot lock from her room (and in fact, functions to lock her in her room) and that is an avenue for danger in the novel, Emily's knowledge of the door and the risk that it poses makes it much less of a threat than the maze-like corridors of the rest of the castle that she is not familiar with.

When comparing the well-known scene in which Emily is chased through Udolpho by Verezzi to another famous scene from Horace Walpole’s The Castle of Otranto, where we find characters in a similar situation, I note the ways in which knowledge of space functions in creating fear. In Walpole's writing, Isabella knows where she is going and what she is looking for and therefore the feelings of terror have to come from some other unknown; in this case, it comes in the form of a race against time, terrified that Isabella will not make it to safety before Manfred catches up to her. In Radcliffe's work though, terror is purposefully linked to not knowing. While Emily is running from Verezzi, he is not particularly close to her and struggling to find her in his drunkenness, so the threat is not as immediate. However, the feeling of Emily 
being lost in the maze, of not knowing where she is, what is around her, and which way she needs to go to be safe is what functions to create the sense of terror in the scene. While the male version of the chase feeds off of the incredibly situational instance of the villain and the prey both racing toward the trapdoor, the female version of the gothic chase taps into the everyday fears of women who feel powerless in their spaces and their lack of knowledge.

Knowledge is a powerful force in gothic works; it keeps characters safe, allows them to solve the supernatural mysteries surrounding them, and separates those the reader should strive to imitate from those they should try not to become. Education in Radcliffe's Mysteries of Udolpho comes in many subtle forms and often appears as agency- agency in their homes, and in their relationships. Specifically, the knowledge of space functions to overcome the daily terror of women's lives and highlights the power that they hold in their homes. Without this knowledge, the home is anything but the "woman’s sphere"; instead, it becomes a place of insecurity, vulnerability, and fear. Through the subtleties in this gothic plot, Radcliffe advocates for women's knowledge as a means to their authority in their own homes. While the gothic castle may represent imprisonment and patriarchal trappings, it also functions to illuminate the power that women do have over spaces and how their knowledge is the quality that can overcome terror imposed on them by living in a man's world. 


\section{CHAPTER III: BIRTHING KNOWLEDGE: SHADOW EDUCATION AND}

\section{REPRODUCTIVE SCIENCE IN MARY SHELLEY'S FRANKENSTEIN}

Some of the most popular gothic works were written in the nineteenth century as technological, scientific, and medical advancements were accelerating at incredible speed, and they inspired both excitement for the future and longing for earlier methods that were comfortable. Mary Shelley's Frankenstein: Or, The Modern Prometheus (1818) capitalized on the rapidly expanding ideas and fears surrounding education and science to create one of the most well-known and easily identifiable gothic novels; it raises questions about learning, reproduction, and the boundaries of scientific experimentation and the pursuit of knowledge. In the eighteenth and nineteenth centuries, reproductive medical science was undergoing a rapid and controversial change, and Shelley's position as an educated woman who experienced multiple pregnancies and miscarriages would have situated her firmly with those invested in this evolution. The influence of men in the scientific community of the time is clearly evident in Shelley's work and is intrinsically tied up with the presentation of education in the novel. Shelley explores the ideas of scientific experimentation and "progress" and as such, education becomes a core element of the story's plot. From the very beginning, the reader follows Victor Frankenstein’s journey through his education and watches as his intelligence and ambition lead him to the scientific creation of life. While Victor's education seems to be at the core of the novel, it is perhaps more interesting to compare his training to the education of the women in the novel. While Ann Radcliffe's Emily St. Aubert survives because of the domestic and spatial education that prepares her to navigate under pressure, Elizabeth and Safie DeLacey receive just as rigorous and wide an education as Victor does. And while Elizabeth's intelligence allows her 
to be, in Victor's mind, the perfect companion, Safie's intellect is what saves her from a life imprisoned by her father and helps her fight for the life she wants.

Alongside a youthful Victor is his cousin and soon-to-be bride, Elizabeth; the two are educated side by side in the Frankenstein household. Elizabeth’s shadowing of Victor's education -- and her divergence from it when he begins to seek beyond the accepted methods of learning -- is an illuminating place to begin understanding the types of education that Shelley seems to advocate. The Creature's narrative is the other point where education plays an integral role; here, we get the narrative of Victor's Creature, and the Creature details how he came to possess speech and understanding of the world around him. In the formative moments of his life when he is being educated by the DeLacey family- unbeknownst to them- there is also another woman present who is receiving the exact same education. Safie has recently come from Turkey to France to live with the DeLaceys, and they take it upon themselves to educate her in the ways of the world. It is in fact her education that the Creature shadows and learns from and the subjects that she is being instructed on are vast and robust. This scene is a more concrete peek into the type of education that Shelley imagines for women. Importantly, in both Elizabeth and Safie's situations, female education is not an individual, fully private experience but a shared, synchronous one; Elizabeth learns through Victor and builds from what he learns to then further her humanistic interests, creating an interdisciplinary range of knowledge. He, however, does not learn through her - he seems uninterested in literary and philosophical study. The Creature, however, learns through Safie; her mediation of the educational experience inspires, in the Creature, a more philosophical and holistic literacy experience.

Through these characters, Shelley advocates for the vigorous education of women, but she relates this progressive idea to her gothic work in a unique way- through her male character, 
Victor. Shelley sets up two examples of rigorously educated women and the lives that they lead in comparison to Victor and his knowledge of creating life with its ensuing fallout. By showing the pain, terror, and disaster that result from Victor's attempt to give birth, Shelley privileges the centuries of information about reproduction that women and midwives had over the newer, scientific methods being practiced by contemporary obstetricians. Victor's lack of knowledge of birth and the ensuing events create terror, and his non-understanding of the life that he has created highlight the power of knowledge over terror. This novel also clearly demonstrates the cycle of terror that begins with men; Victor's fear of creating an independent and intelligent female creature who can then create life herself, leads him to exorcise his fear directly on the woman's body, by destroying her completely. The daily terror, created through male threats and violence, that women face is illustrated in gothic literature and is an immediate result of the internalized terror that men experience, and is rooted within their fear of women's power and agency. Through an understanding of the changes in medical techniques around Shelley’s time, specifically including the shift from midwifery to obstetrics, I show that Frankenstein engages in the discussion of the removal of women from the birth process and their replacement by men with scientific instruments. In this I illustrate how Shelley advocates for women's role in medical science and their procreative education.

\section{A Contemporary View of Terror and Education in Birth}

Shelley was born just before the nineteenth century and as such, her views on education and terror were particular to her position and time. Born to influential thinkers, writers, and progressives Mary Wollstonecraft and William Godwin, Mary Shelley’s perspective on education and terror in the nineteenth century would have been more liberal than most. However, 
it is important to keep in mind that no matter how progressive she may have been, her perspective and opinions were still very different than ours today. In a post \#Metoo world, we have begun to talk about the inherent dangers and daily fears that women face in a much more open and empathetic way. This discussion makes studying Shelley and her work all the more important and relatable; the story that she tells of the dangers of men forcefully inserting themselves into women's sources of power in her time highlights that she, as a woman in the nineteenth century, also experienced the cycle of terror at the hands of men. It is important, though, to recognize the society that she lived in socialized her to fear the rapid progress, experimentation, and discovery of Enlightenment science and no matter how progressive she was, there would still have been certain prejudices and fears ingrained in those who do not have time to fully understand a new discovery before another is revealed. Shelley herself was educated in contemporary experimental science, and it is no wonder that these discoveries about the human body and the fear that they inspired influenced her work in the gothic. Ellen Moers notes that, "Mary Shelley is said- and rightly- to have absorbed into Frankenstein the ideas about education, society, and morality held by her father and her mother. She is shown to have been influenced directly by Shelley's genius, and by her reading of Coleridge and Wordsworth and the Gothic novelists” (94). Similarly, her life as the daughter of a famous pre-feminist writer and educational reformer show up in her writings as an intense focus on education, learning, and their benefits. Shelley would also have been concerned with changes in medical science taking place in reproductive and birth techniques with the change from midwifery to obstetrics, as she herself suffered multiple miscarriages, deaths of young children, and health concerns related to her pregnancies. 
As noted previously, throughout this work with Shelley’s Frankenstein, I will establish the role of education in women's lives and how Shelley advocates for the real-world education of women. As noted in my introduction, throughout this work, when I refer to women, I will also be talking about a specific group of women. Although the character of Safie will work to push these boundaries a little, it would be irresponsible to claim that Shelley advocated for the education of all races, sexualities, and classes of women. Therefore, in discussing how education works to push back against sensations of terror for women, I will specifically and solely be referring to Shelley's white, cis-gender, middle class women.

Similarly to the work that I did on Ann Radcliffe's The Mysteries of Udolpho, I define terror as a sustained feeling that lasts for the characters throughout the novel; this sensation stays with them, is a driving force behind their actions and inactions, and keeps them alert to surrounding danger. Horror in the work consists of perverse depictions of human bodies, violent scenes of death, and dramatic confrontations between Victor and his Creature; all of these sensations, while evoking an emotional response, are momentary feelings that function as "shock value” in the novel. Conversely, the terror in the novel is created from men's fears of women's bodies, the terror inspired in men by women's education and intelligence, and the lack of knowledge that men have of the birth and the moments surrounding it, and the role of educated women in society; all of these were concerns of Shelley's time, and her readers would have related to these social concerns and considered the dangers in their own world while reading. Similarly to this general and realistic definition of terror, I define education just as broadly; education in this novel, as in The Mysteries of Udolpho, is not limited to academic study but also includes social knowledge that is passed on through generations, including specific knowledges of the female sexuality and reproduction in and before the nineteenth century. In Frankenstein, I 
will look at instances of women's academic education as well as the knowledge and social education of women throughout the years in the matter of birth, and the terror inspired by men's lack of knowledge in these realms. In reading Shelley's work, I am connecting this gendered and social knowledge with Elizabeth and Safie's roles and survival of (or, failure to survive) their particular terrifying situations; I am also connecting this particular realm of knowledge to Victor's lack of knowledge in the birthing room and the terror and disaster that this creates.

In Frankenstein, I find that Shelley advocates for women's place in medical and scientific practices through her portrayal of a disastrously unsuccessful male, science-driven birth. In the first part of their work The Madwoman in the Attic (1984), Sandra M. Gilbert and Susan Gubar lay the groundwork for their later analysis of Mary Shelley's work. They note that:

the female artist may, like Mary Shelley, conflate anxieties about maternity with anxieties about literary creativity... Moreover, conditioned to believe that as a house she is herself owned (and ought to be inhabited) by a man... In other words, even if she does not experience her womb as a kind of tomb or perceive her child's occupation of her house/body as depersonalizing, she may recognize that in an essential way she has been defined simply by her purely biological usefulness to her species. (88)

This idea parallels my argument about spaces, homes, and women’s power in The Mysteries of Udolpho, but what I believe is important to note for this discussion of Frankenstein is the idea of a womb as a tomb and the realization that certain women may feel depersonalized by pregnancy. While this theory is incredibly useful for our understanding of Shelley as an author, I do not agree with Gilbert and Gubar's implication that most women writers felt this sense of terror or felt entrapped by pregnancy; it is important to distinguish, especially in a nineteenth-century 
context, the difference between women who wanted to be mothers and women who did not but had no other options. For every woman like Shelley, there was certainly another who cherished and desired pregnancy and motherhood; considering that this feeling of entrapment might have been true for Shelley and many other women but was certainly progressive and shocking for their time, is important to understand the relevancy and uniqueness of the story that Shelley designs. For my purposes here, it is important to understand the connection that Shelley and others like her would have felt between becoming mothers and the daily terror of womanhood. Shelley herself nearly died as a result of a miscarriage and for progressive and educated women, the risks of childbirth for family lines would have felt daunting and terrifying. The relationship between womb and tomb is clearly evident in Frankenstein, and it is interesting to consider the moment of the Creature's birth as the start of all the characters' deaths. While I think the above quote from Gilbert and Gubar ignores the uniqueness of Shelley and other progressive female authors’ feelings about pregnancy, it is a great place to start to consider where the terror in Shelley’s story about birth stems from.

Frankenstein contains one of the most iconic scenes of terror that has been reproduced repeatedly since it was first published in 1818. In fact, it is still one of the most well-known and widely used representations of terror that we see each and every Halloween season. The progeny that Victor creates is simply terrifying when represented on stage and screen: a large, green monster with metal spikes and stitches in his head, the echo of a mad scientist who utters the phrase “It’s Alive!!” -- these have become conventions of genres of horror and monstrosity. The depiction of the genesis of artificial life in Shelley's novel has inspired terror for well over two centuries, and the moment of creation that comes early in the novel is perhaps the best example of the lasting terror that the novel creates. Shelley writes: 
It was already one in the morning; the rain pattered dismally against the panes, and my candle was nearly burnt out, when, by the glimmer of the halfextinguished light, I saw the dull yellow eye of the creature open; it breathed hard, and a convulsive motion agitated its limbs... but now that I had finished, the beauty of the dream vanished, and breathless horror and disgust filled my heart. (35-36)

Shelley sets the scene and creates a lasting motif of “dark and stormy nights” that becomes a trope of gothic and horror stories. It is no wonder that some of the earliest representations of this story on the screen make storms and electricity integral parts of the creation of life. By creating a male character who usurps women’s role in creation, Shelley draws a comparison between Victor as creator and women as Mothers. The scene of creation in the novel mimics women's labor and birth; Victor states that, “After days and nights of incredible labour and fatigue, I succeeded in discovering the cause of generation and life; nay, more, I became myself capable of bestowing animation upon lifeless matter... A new species would bless me as its creator and source; many happy and excellent natures would owe their being to me” (Shelley 32, 33). There is a power in women's bodies that allows them to create life, and Victor uses science and technology to claim that power for his own. Diana Perez Edelman defines this real-world connection succinctly when she states that, "The ruthless patriarch who purses the womb for his own ambition is not just a fictional Gothic plot, but also the story (according to some) of the way in which male midwives wrested control of the birthing room and the bodies in it from women, and of the monstrosity that resulted from this challenge to traditional boundaries” (Edelman 228). A realm that had been ruled by women for centuries, reproductive science and birthing techniques afforded women a space for agency and authority; just like Victor who starts his 
experiments to gain a power that no other man had, male obstetricians and scientists wrestled this space of agency and power away from the working class woman for their own use.

\section{The Role of Education in Understanding Male Fear of Women}

One aspect of the rapidly changing world of the late eighteenth and nineteenth centuries was the expansion of science and scientific experimentation. Shelley herself was known to have attended several scientific demonstrations, first as a young girl with her father and then later with her lover turned husband, Percy Bysshe Shelley. One of the most well-known and radical scientists of the early nineteenth century was Johann Wilhelm Ritter, who was infamous for his experiments with animals and his use of “water divining, 'geoelectrical' mapping and 'metal witching'” which eventually lead him to work with the revival of animals via electricity (Holmes 186-187). It is also assumed, but not proven, that this experimentation led him to the application of his ideas on dead human beings (187). Although this experimentation was frowned upon, it was quite sensational, and Ritter was well known in his time. Mary Shelley, who was no stranger to medical and scientific demonstrations, would surely have known about Ritter’s work and experimentation and the concern about experimenting on human subjects is clear in

\section{Frankenstein.}

Education and scientific experimentation are two major themes of Frankenstein and the majority of the plot hinges on them. Within the first few pages, we are introduced to the type of education that Victor received in his early life and how he ventured forth in his young adult life to further his education at the university. This type of education was becoming common in the early nineteenth century, and most young people from upper- and middle-class families viewed the home as the ideal site for education, and girls' whose education was "modern” did not have a standard curriculum. Their parent would teach them what they had learned alongside what a 
governess or schoolmistress would (Cohen 447-448). Interestingly, while the focus in this novel is almost solely on Victor, all of the characters around him, including the women, are also highly educated. Victor's narcissistic narrative style completely overlooks the education of those surrounding him in favor of his own exploits. However, in the beginning Shelley subtly compares Victor's scientific education with his cousin Elizabeth's interest in the humanities. Kate Ferguson Ellis summarizes the general opinion of Elizabeth among scholars when she bluntly notes that, "What is not evident to Victor is certainly evident to the reader, however. Elizabeth is not a real force in the novel; she is too superficial and monotonous” (Ellis 195). I propose an alternative reading to Elizabeth here that does not see her as a vapid, useless ornament but instead views her as I theorize Shelley intended: as a point of comparison for Victor and his gross misuse of scientific experimentation.

As children, Victor and Elizabeth were educated together in common subjects like Latin and English but were also given the freedom to learn about their passions and interests. Victor notes that, "I delighted in investigating the facts relative to the actual world; [Elizabeth] busied herself in following the aerial creations of the poets. The world was to me a secret, which I desired to discover; to her it was a vacancy; which she sought to people with imaginations of her own” (Shelley 20). Victor's love for and eventual obsession with science is, in Victor's mind (as expressed through Shelley's narration), much more focused than Elizabeth's -- he describes himself as being left to his studies to "investigate" "facts" in the "actual world" while she "busies herself" with "aerial” matters like creation, imagination, and poetry. Her broad studies in the humanities lead Elizabeth to a much happier young adult than Victor, who dedicates his time in an obsessive manner to his academic pursuits. This does not make Elizabeth inferior to Victor -he notes that "neither of us possess the slightest preeminence over the other; the voice of 
command was never heard amongst us; but mutual affection engages us all to comply with and obey the slightest desire of each other” (25). While Victor claims that he and Elizabeth are equal, he does not articulate in what ways they are equal; it is clear from his narration of her affinity for literature and poetry that while yes, this is a type of education, he does not seem to hold it in the same esteem that he does his scientific study. As a progressive, scientific man, he values the idea of an educated and equal woman, but in practice, he is instead training Elizabeth to be the perfect wife for himself. He values education, and therefore she is educated; Victor views their entire intellectual relationship as the molding and creating of his future wife, someone with whom he can be affectionate and desire and "have and hold, 'til death”. However, Elizabeth’s affinity and passion for literature and poetry speak more to her interests, character, and morality than to the woman that the Frankensteins are trying to mold her into. In fact, her ability to think about life narratively, a quality she was inadvertently taught by the Frankensteins, allows her a wider understanding of actions and repercussions. I argue that Elizabeth's humanities education is what Victor is lacking in his devotion to scientific discovery. Without this understanding of the human experience, Victor throws himself into a horrifying experiment without considering the moral and humane implications of his actions. Elizabeth's education was no less rigorous in her youth and yet, her moderation and ability to see beyond simple academic learning and to view the world around her through a narrative lens allows her a more general and beneficial social education.

At this point in the novel, Shelley has established both Victor and Elizabeth, who in Victor's retelling shadowed his childhood learning, as having received a similar amount and manner of academic education as they grew up. In considering the relationship between this education and terror, Victor and Elizabeth each handle moments of fear very differently in the 
novel. When Victor returns home upon the death of his younger brother he discovers a scandal; not only has William been murdered, but his missing broach was found in the pocket of Justine, the only evidence that is apparently needed to have her arrested and tried for this crime. He is informed that, "No one would believe it at first; and even now Elizabeth will not be convinced, notwithstanding all the evidence" and Elizabeth declares, "Alas! Who is safe, if she be convicted of crime? I rely on her innocence as certainly as I do upon my own... every one else believes in her guilt, and that made me wretched; for I knew that it was impossible: and to see every one else prejudiced in so deadly a manner, rendered me hopeless and despairing” (Shelley 52, 53). While Victor is the only one who knows the truth that William was the victim of the Creature, Elizabeth is staunchly arguing for Justine's innocence. She claims that she knows the girl well and while everyone else is blinded by prejudice of a young girl who was framed with an important piece of jewelry, Elizabeth's narrative understanding of the world is enough to know that the evidence does not make sense. She does not have an alternative, but she still holds firm to her understanding of the situation and what she has learned over the years of Justine. She thinks about the situation as part of the larger narrative of Justine's life, and she comes to the conclusion that it could not have been Justine; others who cannot widen their scope beyond the situation believe the conclusion given to them and do not question Justine's guilt in killing a child that she loved and cared for. While in the scope of the novel, the death of the family friend is by far not the most horrific event, one must take in consideration Elizabeth’s lived experience up to this point. She has not experienced any of the terrors that Victor or the reader has, so the sudden death of William followed by the arrest of someone close to her might be the most traumatic thing that she has experienced. However, her reaction is noteworthy because she does not carry on in hysterics or have her character tremendously altered because of this event. 
Instead, she remains certain of her narrative understanding of what she knows and her judgments about others and does not let the fear of the situation overcome her.

Elizabeth's reaction to this situation is interesting when compared to Victor's earlier reaction to his purposeful creation of life. While the death of William and the arrest of Justine are terrifying and sudden, Victor spends months planning and preparing for the birth of his own unique creation. He is not only anticipating the event, but he is the orchestrator of it, and yet his response to the moment of birth is less composed and rational than Elizabeth's reaction to a sudden death. Victor recalls that,

I felt my flesh tingle with excess of sensitiveness, and my pulse beat rapidly. I was unable to remain for a single instant in the same place; I jumped over the chairs, clapped my hands, and laughed aloud... This was the commencement of a nervous fever, which confined me for several months...But I was in reality very ill; and surely nothing but the unbounded and unremitting attentions of my friend could have restored me to life. The form of the monster on whom I had bestowed existence was for ever before my eyes, and I raved incessantly concerning him.” (Shelley 39)

Unable to comprehend what he has done and how to deal with his postpartum emotions, Victor becomes manic and is consumed by the terror that he feels having seen the spark of life enter a manufactured body. Not only is he overcome, but the terror incapacitates him for several months. Whereas Elizabeth holds herself steady in the knowledge that she believes in Justine's innocence because of her knowledge of Justine’s character, Victor's lack of knowledge about anything post-birth overcomes him and incapacitates him for an incredible amount of time. Not only is he incapacitated but he is forever changed by this event; the subtle difference here between these 
reactions comes down to the knowledge that both characters possess. While Elizabeth is clueless to the real cause of William's life, she knows Justine, knows the legal system, and knows what to do upon the death of a loved one. Victor, though highly educated and prepared for the process of making and bestowing life, cannot view the situation in a larger narrative sense and cannot think about what to do beyond the moment of birth and what he needs to prepare. He has no knowledge about how to care for and raise a new human, about what kind of support this new life will immediately require, and about what his role as both father and mother means. Victor's inability to see beyond the end of his experiment and instead see this as one action in a life story that will cause several reactions, allows him to be overcome by terror in a way that Elizabeth is not; these instances both represent the most traumatic episodes of these characters' lives up to this point, and I have demonstrated how the knowledge to view situations as a series of building blocks in life's story instead of as a standalone experiences is the key factor in surviving and coping with these sensations of terror.

It is also important to note, at this point, another example of how Victor's lack of humanistic knowledge influences his actions and creates debilitating fear. After the reader has followed the Creature's narrative up to the moment where he is reunited with Victor, he asks his creator for just one thing and then he promises to leave society and Victor forever. He desires for Victor to create him a female partner, someone else like him who will not be afraid of him and with whom he can live out the rest of his life. While Victor initially agrees to these terms, as he begins creating he is overcome with terror of what creating this new life means. He realizes that although he and his male creation have agreed upon the disappearance, "she, who in all probability was to become a thinking and reasoning animal, might refuse to comply with a compact made before her creation” (Shelley 118-119). Victor is specifically terrified of the 
possibility that his female creation might think for herself and dictate where she lives and how she spends her time after birth. Instead of deciding to teach this creature, as he is aware is possible from the education of his first creation, he is so horrified by her potential power over her own body, her own choices, that he chooses to completely destroy the corpse. This moment calls back to Victor's childhood with Elizabeth, where he describes them as being on equal footing and notes that "the voice of command was never heard amongst us" (25). As mentioned earlier, it does not seem that this is genuine equality, but the illusion of equality that men expected in marriage; the female creature and her very real potential for equality with the male creature is terrifying and disturbing to Victor. A woman who was not educated under strict observation and not on approved patriarchal subjects is the most terrifying creature of all. As the cycle of terror shows, women's education and agency terrify men and in retaliation, they terrify women through physical and sexual threats.

While thus far I have focused on the education of the white, cis-gender, middle-class characters of the novel who have their basis in Shelley's own world and experience, I now want to turn toward the particularly intriguing and often overlooked character of Safie. While the Creature is hiding from the world, he stumbles upon the DeLacey's home and hides himself somewhere so that he can observe the family without being seen. The arrival of Safie, betrothed to Felix DeLacey, the son of the elderly, blind DeLacey, sets many changes in motion. She does not speak the same language as the DeLaceys, and they set about teaching her like a child. The Creature takes advantage of this opportunity and shadows her education, learning to read, write, and speak. The Creature notes that, "she and I improved rapidly in the knowledge of language" which is represented as quite a feat for Safie, even though she is already fluent in a different language (Shelley 82). Language learning is difficult for an adult who is already situated in their 
own language practices and yet, Safie progresses as rapidly as the Creature who is learning these concepts for the first time. Not only is she learning quickly, but she is also being taught from texts about history, social structures, and gender. The Creatures learns, “of the difference of sexes; of the birth and growth of children, how the father doated on the smiles of the infant...how all the life and cares of the mother were wrapt up in the precious charge” (84). Everything that the Creature is learning is in the shadow of Safie's education, and it seems that she is receiving a robust education far beyond the typical woman’s domestic instruction.

We are also told that in growing up in Turkey with her Christian mother, Safie is taught the Christian religion and to "aspire to higher powers of intellect, and an independence of spirit" that makes her a progressive woman in her society (86). Here Shelley creates a progressive and intelligent female character who is unlike any of her other characters (besides, perhaps, the Creature); in typical gothic fashion, the "other” of both a woman and foreigner should have been treated as the evil influence in the novel, but here, Safie is a blessing for the DeLacey family and she is educated and cared for. This is an unusual break from convention in what becomes one of the most important gothic works. Safie is no secondary member of the DeLacey family; she is loved and receives a wide-ranging and vigorous education from her new family. Similarly to the type of education that Shelley herself received, eighteenth-century homes provided a unique education to their daughters based on the values of each “individual parent, moralist, educationist, schoolmistress or girl herself,” who could write their own curriculum (Cohen 452). While Safie’s story only takes up a very short portion of the narrative, her unique situation begs to be better understood. This is perhaps the most meaningful female character of Shelley's novel and seems to best represent the progressive and idyllic views of women's education that Shelley inherited from her late mother. Jennifer Buckley gets to the heart of the matter and writes, 
“Indeed, the novel's long section on the creature's education at the De Lacey hovel reminds the reader that Shelley was the daughter of Godwin and Wollstonecraft, two staunch advocates of the influence of education over innate character." Continuing, she notes that "one cannot help but wonder if Shelley's inclusion of both the effects of Victor's maternal imagination and the effects of the creature's education are an extension of her parents' debate regarding natural and nurtured individuals” (57).

Considering the relationship between Safie’s education and terror, it is important to note that she experiences perhaps the most harrowing situations in the novel besides Victor and the Creature. After her father flees Italy before being arrested, he leaves her behind to eventually catch up to him, and Safie finds herself at a crossroads. Without her father present, Safie resolved in her own mind the plan of conduct that it would become her to pursue in this emergency. A residence in Turkey was abhorrent to her; her religion and feelings were alike adverse to it... She hesitated some time, but at length she formed her determination. Taking with her some jewels that belonged to her, and a small sum of money, she quitted Italy, with an attendant, a native of Leghorn, but who understood the common language of Turkey, and departed for Germany... and the Arabian was left alone, unacquainted with the language of the country, and utterly ignorant of the customs of the world. (Shelley 88)

Safie faces very real danger as a foreign woman alone in a country whose language she does not speak and whose customs she does not know. Not only does she orchestrate her own escape, but she is also able to take care of herself in a new and unknown environment. Her story of searching for religious and intellectual freedom with a man who values the conversation he has with her is jarring in the middle of this narrative. Not only do we find a woman who is educated, intelligent, 
and has agency over the course of her life, but her story revolves around her fighting to live the life she wants with the freedoms she deserves. She faces the threat of terrifying situations in a patriarchal world and overcomes them all in the name of pursuing the ability to have agency in her life.

\section{Claiming the Female Body: Obstetrics vs. Midwifery}

In the novel education plays an important role and the parallels between Victor's experimental reproductive science and the developments of obstetrics in Mary Shelley's time are too many to ignore. Around the beginning of the nineteenth century, the concept of the human body as a subject of scientific investigation resulted from changes in Enlightenment philosophy, art, theology, and the evolution of scientific thought about human nature. The investigation of the nerves is pivotal for our modern conception of both art and literature because of their use of the theory of aesthetics (Haekel and Blackmore 9, 12-13). In their collection Discovering the Human: Life Science and the Arts in the Eighteenth and Early Nineteenth Centuries, Ralf Haekel and Sabine Blackmore write that, "Enlightenment and Romantic aesthetics and poetics can only be understood against the backdrop of the new scientific understanding of the human and, in turn, the scientific discoveries only make sense when considering the cultural conceptions of human life” (19). In the eighteenth century, startling experiments in medicine, like William Harvey's on the circulation of blood in 1628 and Anton Van Leeuwenhoek's discovery of blood cells, micro-organisms, and sperm in 1670, all influenced the popularity of live human specimens that provided science mixed with spectacle (Buckley 39). At its core, Frankenstein is a birth narrative; in a seemingly impossible feat, Victor usurps women's reproductive power and steals their role in the creation of life. In an almost exact reflection of this, the newly formed 
medical branch of obstetrics very quickly claimed the right to take over the medical procedures surrounding birth from the centuries of traditions of local midwives. Where birth was once a woman's territory and there were centuries worth of information passed down from mother to mother, midwife to midwife, new developments in experimental science allowed male doctors to claim this space as their own. Women were doubly disempowered by their loss of a class of professional women (whose knowledge was appropriated by men) and loss of control over their birthing narratives, which were suddenly regulated to “old wives’ tales” (McDermott 2, 8).

While Shelley was aware of contemporary advances in experimental and medical science, she would have had a particular investment in these developments of reproductive science. Her life, from her birth until at least her middle ages but probably to the end of her life, was dramatically influenced by the relationship between birth and death; her mother, well-known author of A Vindication of the Rights of Women (1792), died after giving birth to Mary, a shadow that would follow her for the rest of her life. Shelley then became pregnant as a young adult, and her tumultuous relationship with Percy Bysshe Shelley resulted in many miscarriages and the death of three young children (Moers 319). Moers highlights the unusualness of this lifestyle by comparing it to our modern times by stating that, "The harum-scarum circumstances surrounding her maternity have no parallel until our time, which in its naïve cerebrations upon family life (and in much else, except genius) resembles the Shelley era” (97). She was likely pregnant for most of her life between the ages of sixteen and twenty-three and considering her welldocumented habit for reading, she more than likely would have been reading pregnancy literature (Buckley 247). Shelley’s history makes it clear why she would be particularly invested with this change from traditional midwifery to the more scientific approach of male doctors. 
The rapid shift from midwifery to obstetrics in the nineteenth century is representative of a much larger social anxiety of the power that women held over their reproductive abilities and the lives that they created. With the rapid expansion of Enlightenment science and its emphasis on rational thought and progress, new information about the human body was constantly being revealed and what had previously been "women's work” became an area of fascination and study in male scientific understanding. Female midwives found themselves displaced from their work, in favor of medical doctors who oftentimes intervened in the birth process with medical tools regardless of their necessity (McDermott 4). There was also a growing distrust in female midwives as they held an enormous amount of power over birth and new life; their ability to safely (or in some cases unsafely, depending on the desires of the mother) deliver babies and their power over what happened in the moments after birth created doubt in the minds of men about what exactly their powers were. Edelman notes that "the source of horror in regard to female midwives was primarily about challenges to male dominance in social, legal, and family matter, for the female midwife could circumvent these structures in the secrecy of the birthing room" (238). Female midwives were a concrete example of the educated women that men in the eighteenth and nineteenth were terrified of. Similarly to Victor's terror surrounding the possibility of an educated, autonomous female creature who could create a new race, men were terrified over the control that female midwives exerted over life and death in the birthing rooms.

Part of this change from midwives to obstetrics was due to the fact that there was a shroud of mystery about birth that had until then been known by only the small group of women practicing midwifery. These male doctors sought to claim this knowledge for their own and at the same time displace women from their positions of power and replace them with systemically and academically educated men. We see this reflected in Frankenstein where there is a male 
creator, a scientific birth, and no maternal instinct in Victor when the Creature comes to life. The disastrous results of this male-driven birth highlight the value of women's domestic intelligence and practical education as midwives.

While Victor is at first blinded by the intellectual process of creating life, the terror caused in the actual moment of creation is long lasting and colors the rest of his scientific exploits. In fact, as discussed above, Victor is not able to follow through with the process again when the Creature offers to leave society behind if Victor creates a partner for him; he begins the process but before he brings the body to life, he destroys it in a fit of terror. His reasoning, however, is not what we would initially assume; he is not regretful of his previous experimentation and afraid of crossing the line into God-like territory again. No, what Victor is afraid of is what will happen after his new creation is no longer under his control; he fears that she may have a mind of her own and not agree to the terms set by the two "men" surrounding her creation and that she may choose to wield her bodily power and reproduce, reclaiming the power of reproduction from Victor. In his debate on whether or not to create a female creature, Victor worries that, "Even if they were to leave Europe, and inhabit the deserts of the new world, yet one of the first results of those sympathies for which the daemon thirsted would be children, and a race of devils would be propagated upon the earth, who might make the very existence of the species of man a condition precarious and full of terror” (Shelley 119). This fear of the lives that the female creature could produce is more important to Victor than his health, which he does not reference until a full paragraph later. Indeed, Frankenstein is a horror story of a society exclusively for males who are so afraid of female decision-making in sexuality and birth that like Victor, they turn to science in an attempt to control and repress women (Mellor 355, 363). Afraid 
of this power that only women possess, Victor works to withhold reproductive power and control from them, most clearly through the female Creature.

From my current lens after the \#Metoo movement, it was interesting for me to note the feeling of confidence in making the right decision that Victor feels when he decides to destroy his female creation before she is brought to life. I was immediately struck by the parallels with women's struggles with obtaining abortions and the guilt that they are often forced to feel after their choice has been made. In deciding to abort the creature, Victor asks himself: "Had I a right, for my own benefit, to inflict this curse upon everlasting generations? ... I thought with a sensation of madness on my promise of creating another like him, and, trembling with passion, tore to pieces the thing on which I was engaged” (Shelley 119). In fact, Victor chooses to violently abort his child for fear of what their life would be after birth, and the only feeling he has after the procedure is one of relief and satisfaction knowing that he made the right choice for everyone. When looking for instances of knowledge and terror that were related to each other, it seemed important to dig into why Victor felt no terror surrounding his choice of abortion, whereas women have historically always lived in a sense of terror during every aspect of pregnancy; the terror of health complications and the possibility of death for both the mother and the child, the terror surrounding any type of medical intervention during pregnancy because of social taboos, the terror of obtaining abortions which until recently had to be done illegally and incredibly unsafely (though historically had not always been illegal). Once Victor sets his mind to aborting his creation, he completes the process right away, with no issues; this stands in stark contrast to the difficulties that women have faced in receiving abortions and the role that female midwifes played that male obstetrics would not. When a mother wanted an abortion for whatever reason, "These midwives transgress their sacred duty over life by facilitating newborn death and 
thus become 'monstrous'; at the same time, these midwives offer hope and power to the underprivileged, those who could not afford to support young children in a climate hostile to the poor” (Edelman 231). The guilt and shame associated with pregnancy for women has been pervasive and yet Victor, the male with reproductive power, is able to make the "right" choice to abort his future child and not only faces no repercussions for this decision but is instead validated in knowing that he made the best choice he could. Shelley's Frankenstein is a birth story at its core but what comes after says a lot about the differences between men and women's power, agency, and rights; yes, Victor ultimately pays for his actions of usurping women and God with his death, but he manages to do so in a way that he believes to be heroic, protecting society from his creation. Meanwhile, all the women in the novel face horrible deaths that are just footnotes in the novel; Justine is hanged for murder, the female creature is aborted, and Elizabeth is brutally killed by the creature on her wedding night. None of these women are guilty and yet, they all pay with their lives for Victor's error; in a novel about the terror surrounding reproduction, all these women must die simply because they are women. Their procreative power must be controlled since Victor was unable to control his creation; the fear of the power of women's bodies - and minds -- and what they can produce literally brings about the death of all the women in the story. For a novel about birth written by such a progressive and unique woman in her time period, the treatment of women in the novel is noteworthy. In fact, I argue that outside of these small vignettes of women's education, Shelley advocates for women’s place in reproductive science through her male character of Victor. She demonstrates that similarly to obstetrics of the time, Victor's possession of the scientific understanding of birth does not qualify him to play a substantial role in the creation/birth process. In fact, his intervention has disastrous results. Through this depiction of a male scientific birth, Shelley illustrates the benefits of women in the 
procreative process; unlike Victor, they have centuries worth of knowledge about how to create a life without causing the stress and sickness that Victor experienced, and they can properly care for the new life in the moments after. Obstetricians and man-midwives were so eager to establish themselves as legitimate in reproductive science and medicine that they hinged their suitability on claims to reason, rationality, and education (Buckley 48-9). Shelley also illuminates how quickly men can justify abortion when it is their choice; women have suffered for centuries with guilt, shame, and legalities surrounding abortion but within a year's period of inserting himself into the world of reproduction, Victor understands the importance of being able to choose. When it is for "science" and decided by a male doctor, abortion is a viable option where it never had been for women. Shelley's creation of Victor represents everything that women midwives are better at and more suited for; she heavily criticizes the role of men and scientists in this women's realm and the new procedures that they impose upon vulnerable women when not necessary.

\section{Conclusion}

As Gilbert and Gubar note in their work, for many progressive and educated women in the nineteenth century, pregnancy was a form of entrapment and death. Shelley's narrative plays on this idea as she illuminates the complexities and evolution of reproductive medicine. As discussed above, Shelley highlights the importance of her female characters' education by setting them in comparison with the delusional and unstable male scientist. Even though the narrative, as told from Victor's perspective, greatly overlooks the education of the women surrounding him, they are educated and to great lengths; Elizabeth receives exactly the same education growing up that Victor did, plus she self-educates in literature, the arts, and the humanities to build a broader repertoire of knowledge about narrative, probability, and problem solving. It is by shadowing 
Safie's education that the Creature learns what he does. In fact, the education of both of these women is also the vehicle for the two most intelligent male characters. The very subtle inclusion of women's education highlights much of what Mary Shelley thought about education: that men and women should receive the same type, that women should not be withheld from certain subjects, and that women were just as capable of learning and benefiting from robust educations as men were.

While a lot of the focus in discussing Frankenstein is on the new and exciting experimental science that was happening in the nineteenth century, attention needs to be paid to the criticism of obstetrics in the novel. Shelley's male, knowledge-obsessed scientist pushes all boundaries and ethics to accomplish a feat he never stopped to consider if he should attempt. His inability to think of life in a narrative structure and his actions lead to ruin and disaster, and while many readers cite the moral of the novel to have something to do with "playing God," as I have demonstrated above, perhaps we should be more interested in the complete elimination of women that Victor's success indicates. The transition from traditional midwifery to obstetrics was controversial and as a progressive woman who also suffered many pregnancy complications, Shelley's novel can be seen as a critique of men overtaking a professional woman's domain. While Victor's perversion of obstetrics ends in death and despair, Shelley demonstrates the need for women and their knowledge in the realm of reproductive sciences.

In our post \#Metoo society, I cannot help but notice the consequences of terror on women's bodies; Victor fears the female Creature and her ability to create and raise her own race all on her own, Elizabeth's death is orchestrated by the Creature on her wedding night to steal Victor's future children from him just like he took the Creature's, and of course, Victor's complete takeover of the creation and birthing process in such a way that would eliminate the 
need for women and their bodies and effectively stunt their power. Recent heightened concern about women's rights and control over their bodies and their ability to choose abortion, if they so wish, also provides an interesting lens through which to look at Shelley’s work. The lack of terror or guilt that Victor feels when he aborts his creation -- incredibly late in term as she is a fully formed being at that point -- sheds light on men's absurd privilege and power in society. Whereas women were not legally allowed abortions and were subjected to incredible amounts of guilt and shame for even contemplating the idea, Victor makes the choice and portrays himself as heroic for doing so. Shelley’s gothic work highlights the terror that men feel in regard to the power of women, especially when educated, to control their own bodies and, consequently, the terror that women are made to feel because of the fear that men have of their bodies. This cycle of terror begins with men's need to overcome their fear of women's bodies and power by asserting their masculine dominance and avenging their fears of women by creating a hostile and terrifying world for women to live in. Men’s need to overcome and defeat the terror that they feel from intelligent and autonomous women directly creates a world in which women experience terror at the hands of men and their social structures every day. 


\section{CHAPTER IV: THE EVOLUTION OF GOTHIC EDUCATION: INDIGENOUS AND MODERN KNOWLEDGES MIXING IN SILVIA MORENO-GARCIA’S MEXICAN GOTHIC}

In the two-hundred and fifty years since Horace Walpole’s Castle of Otranto (1764), the gothic genre has expanded and evolved alongside our culture, and while elements and tropes of Otranto are still present in the genre today, gothic stories have taken on a life of their own; their presentation has far surpassed anything Walpole could have imagined. Not only did later writings redefine the genre and layer its meaning, but with the development and popularization of film, gothic narratives took on new lives. In keeping with the popularization of Ann Radcliffe's gothic works of the 1790s, women authors continued to publish successful and enduring novels through the nineteenth and twentieth centuries; as these women continued evolving the gothic genre over the centuries, views of women, education, and social sources of terror all progressed as well. Having already worked with the classic gothic novels The Mysteries of Udolpho (1794) and Frankenstein: Or The Modern Prometheus (1818), I jump through time to analyze a modern gothic novel by Silvia Moreno-Garcia entitled Mexican Gothic (2020), in an attempt to demonstrate the continued necessity of gothic literature for women writers to express the daily terror experienced simply by being a woman. I will highlight how the themes of women's education and their agency are still at the center of the creation of modern gothic terror. Previously, I have used my modern perspective to understand the concerns in works from the eighteenth and nineteenth centuries with women's experience of terror that is created by men but acted out upon women; now, I will use this perspective to illustrate the ways in which this cycle of terror is perpetuated today and how modern gothic works find terror in contemporary perspectives on this cycle. 
Mexican Gothic, set in 1950s Mexico, finds Noemi Taboada at the gothic mansion High Place investigating her newly married cousin’s sudden illness where instead, she finds a supernatural mystery tying the sinister Doyle family to the house where the women of the novel cannot escape. A complex system of supernatural mushrooms consumes the castle and its inhabitants and the patriarch of the family, Howard Doyle, has discovered how to fuse his consciousness with the system, allowing him to live forever through the bodies of his direct descendants. He is obsessed with creating "ideal specimens" and entraps Noemi, with her "exotic" skin and heritage, to bear his children/future bodies. Although this novel is written over two hundred years after Shelley's and Radcliffe's, issues surrounding women's education and their maternal roles are still at the center of the story. Noemi dreams of earning a master's degree and avoiding being trapped in the role of wife and mother. She must use her cultural knowledge and education in academic subjects like anthropology to save herself from becoming the next reproductive tool of the Doyle family. She learns about mycology from the young Francis Doyle and uses this knowledge to understand the supernatural mystery of the family. The author Moreno-Garcia herself is a highly educated woman, having earned her MA in Science and Technology Studies, and uses her knowledge to address concerns that still exist about domestic vs. career women. Through analysis of this work, I show how themes of women's powerlessness, social expectations, and their intelligence are still issues in our modern society and aspects of life that “other” women. In the cycle of terror that is perpetuated by men, aspects of women's lives that allow them freedom and agency still cause terror in men who continue to avenge their fear on women's rights and bodies.

Two of the most noteworthy developments of the gothic genre is the way it has spread out of Europe, across oceans, and is written by those that the early gothic genre had identified as 
the "other". For the purposes of this work, I'll be focusing on the spread of gothic literature to Latin American countries and Mexico in particular. Authors of the gothic genre, in general, use past history to address concerns of the present and gothic literature in Latin American countries is no different; this instance is unique however, because the past experiences of Latin American authors is very different from that of eighteenth and nineteenth century white, British authors that came before them. In Carmen A. Serrano’s work Gothic Imagination in Latin American Fiction and Film (2019), she details the similarities and differences of British and Latin American gothic literature in this way:

The addressing of present concerns by conjuring a previous moment in history, so often attributed to the Gothic, mirrors the expression of anxieties associated with the social and political milieu via the vampires, doubles, and live burials of Latin American texts. The texts analyzed here evoke creatures and punishments associated with an illusory bygone time; however, these authors not only summon European Old World castles, labyrinths, and vampires, but they also mention preColumbian gods and myths and age-old temple sand ruins to create nightmares that speak to the particularities of the region's history and culture. That is, authors, often double back to both historical settings, adding to the stories’ mystery and wonder and paralleling the way the Gothicists approached their historical past. (Serrano, 6-7)

While these writings by Latin American authors often look very gothic in form and narratives, their unique history puts an interesting spin on the gothic genre that sets their writing apart from the early gothic works. Instead of just following the models established by early British and 
European writers and creating narratives that follow the status quo of gothic writing, Latin American authors transported the form and used it as a tool to articulate the social and political realities of their culture and time (Serrano, 2). Similarly to what Mary Shelley did with Frankenstein, concerns with scientific and technological advancements lead Latin American authors to the gothic genre; it allowed them to express their concerns with the rapid changes and unknown futures of the world around them. Diana Wallace notes that "the Female Gothic...is shaped by many issues, including national identity, sexuality, language, race and history. It is also the case that the form challenges and complicates such issues and this is why it is of such major literary and cultural importance” (Wallace 10). Like the gothic authors of the nineteenth century, they used monsters to represent how they viewed changes in the premodern era. These monsters often look and act a little differently than Frankenstein’s monster, Mr. Hyde, or Bram Stoker's Dracula; these monsters that Latin American authors created were influenced and pulled from their local and indigenous cultures and evoke layered realities influenced by African cosmography, pre-Columbian myths, regional folklore, and oral histories (Serrano 86). While Latin American authors pulled their inspiration from gothic works of eighteenth and nineteenth century Europe, what they have created has taken on a cultural significance far beyond the original bounds of gothic literature.

Like my previous chapters, before I can begin to talk about fear and education in Moreno-Garcia’s Mexican Gothic, I must first establish what the socialization of fear looks like for the female authors of the time and define who specifically they are. Many of the basics of the socialization of fear stem from the same concerns: power, death, and physical harm. However, in looking at a novel that was written over two hundred years after the inception of the gothic genre, these fears manifest in new and very different ways. For example, in early gothic works 
we see the fear of power manifest as fear of illegitimate rulers and in the oppression of women characters for the benefit of male authority; in Latin American work though, this fear stems from colonization by and subjugation to white and European persons. In the first two novels that I analyzed I found fear located in women's ability to control and make decisions about their bodies and fear in the threat of "otherness", of those that do not look or act like the middle and upper class white Europeans who were writing in the gothic genre. In Latin American gothic though, fear comes from the "otherness" of the very same white class of Europeans who were writing the genre just two hundred years earlier; the power and oppression of colonization that Latin American countries experienced at the hands of invading Europeans have firmly flipped the source of fear in their works to be found in white bodies.

Other sources of fear in Latin American countries stem from women's bodies, their agency, and their intelligence. Unlike the two other gothic novels that I worked with earlier, when I talk about women in this analysis I'll be referencing a much different demographic; we are no longer limited to just the white, middle and upper class, British women because now, I will be referring to all classes of Latin American women as the primary woman discussed in the novel. The female characters here come from different social classes in Mexico, and while Noemi herself is part of the upper/middle class, her family is "new money" and memories of not having much are still close by. She finds help and wisdom in the form of an impoverished local medicine woman in the town surrounding High Place. There is a wide range of classes of women represented in the novel and each of them holds power, agency, and some type of education that allows them to survive their situation. I have been reading gothic novels in my work from a post \#Metoo perspective that calls for representation and understanding of the daily terrors that women face in a patriarchal society and this becomes especially important as I begin to work 
with a modern gothic writings. Moreno-Garcia frames her gothic novel from the perspective that has historically been muted; her Mexican heroine is the type of woman who would only ever have been "other”ed in gothic writing (similarly to the ways that the intelligent Safie was described in terms of her race and foreign religion and her "need" to convert to Christianity in order to live a full life). The \#Metoo perspective that I use in my work calls for a recognition of all women and the cycle of terror that they are subjected to by men who are afraid of their power and potential.

In the same way as the last two chapters, I will be talking about terror as a sustained sensation and the relationship between women's education in the most general, nonhierarchical sense, in surviving the terror inflicted by a male dominated society. As Mexican Gothic was written over two hundred years after the first two novels that I analyzed, I note the evolution of women’s terror, standards for their education, and the ways in which women’s terror and perception of their education has not changed over time. Mexican Gothic here serves as a point of comparison to highlight the ways in which women in our post \#Metoo society still need gothic literature to express their fears, oppression, and the ways in which their bodies are controlled and abused by men. Just as gothic literature functioned as a method for women writers of the eighteenth and nineteenth centuries to subtly reckon with their mistreatment in society, the genre offers the same possibility for women authors of all races, classes, and sexualities to make their abuse evident and convey their terror and the precarity of their situations to their readers. Gilbert and Gubar noted in the 1970s that, "Inevitably, as we shall see, the literature produced by women confronted with such anxiety-inducing choices has been strongly marked not only by an obsessive interest in these limited options but also by obsessive imagery of confinement that reveals the ways in which female artists feel trapped and sickened both by suffocating alternative 
and by the culture that created them" and I believe that this holds true for gothic novels written by women today (64).

One of the most common gothic elements that still plays a pivotal role in women's modern gothic is the entrapment of female characters in a gothic castle; these entrapped female bodies take on new meaning for people who have experienced the consequences of white colonialism within a patriarchal society. Whereas the white women characters in early gothic works were imprisoned in castles by villains who were very clearly defying societal norms, the women of Latin American gothic novels are entrapped by white men who have the "right" to do so, as the women were secondary citizens of colonized lands. Mexican Gothic gives voice to the terrors of women who historically have not had a voice or power to express their situations and provides a modern example of the ways in which gothic literature is still a relevant genre for expressing the darker sides of our world.

\section{Modern Fears of Women's Education}

The recent novel published in 2020 has inspired renewed interest in the gothic novel, as a genre, as well as in the influence of Shelley's Frankenstein, but with new interest in intersectional and transnational representations of women's scientific education: MorenoGarcia’s Mexican Gothic. Like England during and after the social and political upheaval of the French Revolution, and as rising industrialism helped redefine public and private gender roles, Mexico was also forced to take stock of itself during the 1940s. In this transitional period, the country was healing from a period of revolution that dated back to 1910. Globally, they witnessed the beginnings of World War II and soon found themselves tied up with the Allies as 
suppliers of raw materials and other support. This led the country to recreate and redefine their identity as a debate emerged over how the country should portray itself. Progressive and traditional ideals were at tension with each other and what it meant to be Mexican (Rankin 96). Mexico found itself on the global stage, and this brought to light the struggle between progressive thought and traditionalism in the nation. Progressive youth movements arose in Mexico where society had been affected by revolutionary civil war (1910-1917) and rebellion (1926-1929) that divided cultural thinking (Brewster 694, 696). Between World Wars and revolution, Mexico was a changing society and these questions of power, education, and equality were evident in the tension between traditionalist views of women as wives or mothers and progressive ideas of independent women who could significantly contribute to society.

These social and political changes of the time were also reflected in women's roles and the value of their education. With the onset of World War II, more women than ever began entering the workforce, and education saw a large influx of women in teaching and assistant positions. However, this transition was not easy, and requirements for teaching posed some difficulty for women as higher education was elitist and not representative of broader society (Brewster 706-707). Once women became qualified for teaching however, there were more hurdles to overcome and other difficulties to deal with. Teaching in Mexico for women was an incredibly unequal profession that held them to an unrealistic standard. Many women were assistants to male teachers and paid less to do a job which required them to remain unmarried and without children during their employment. The Ministry of Education supported coeducation but maintained lower salaries for women (Lopez 59, 63). While women were being educated and put in charge of educating others, their value and worth was often overlooked due to their sex, an issue that is still present in today's society. All these changes socially, culturally, and globally in 
twentieth-century Mexico resulted in a national transition and apprehensiveness of developing roles for women. This was the twentieth-century Mexico that Moreno-Garcia writes about in her 2020 novel Mexican Gothic, a nation that was not sure how much freedom to give its women and that was still healing from revolutions and wars of the first half of the century.

These social concerns about women’s education are central in Moreno-Garcia’s Mexican Gothic where academic education provides the initial motivation for Noemi. Noemi wants more freedom in her life than what was expected of her in 1950s Mexico City and her progressive view of what women can achieve is in direct opposition to her father's traditional view of women as mothers and wives. Latin American gothic literature reveals that Mexican women writers deal with the country's repressed sexuality and gender boundaries to write women like women and construct their own identity (Estrada 65, 74). We see this reflected in Mexican Gothic where we have an educated and independent young woman as the heroine of the story. Noemi's goal and desire at the beginning of the novel is to earn her master's degree in anthropology; her father promises her that she can enroll in school if she goes to check on her newly married cousin and her sudden illness. Noemi's motivation for the first part of the novel is completely centered on her desire for higher education and avoidance of marriage. Noemí’s desire for knowledge and education are continually at odds with everyone else around her in the novel. She sees education as a means to freedom of marriage and "settling down" that her family wishes her to find. We see that:

Noemí's parents allowed her to attend the Feminine University of Mexico, but they had balked when she declared she'd like to continue her studies upon graduation. She wanted to pursue a master's degree in anthropology... Her father thought this was both a waste 
of time and unsuitable with all those young men roaming the hallways and filling ladies’ heads with silly and lewd thoughts. (Moreno-Garcia 12)

In this work, like in the previous gothic novels I have analyzed, we have the conflict between socially acceptable roles for women and the progressive dreams and ambitions of intelligent women. Unlike Radcliffe and Shelley, who provided their intellectual women with supportive and encouraging families, Moreno-Garcia, in the twenty-first century, has a much more realistic outlook of the ways in which women's education is still considered "lewd" and is a source of terror for men even all these years later. Noemi's family does not support her academic goals and in fact, her father uses these ambitions to bend her to his will and makes her journey to check on the health of her newly married cousin.

Once Moreno-Garcia has successfully set Noemi up as an "outsider" to society, the rest of the novel highlights the ways in which Noemi’s intelligence, education, and curiosity allow her to cope with the terror she discovers in the gothic castle High Place and enables her survival of the nightmare she is thrust into. Related to the concerns about women's education in the novel, the supernatural powers of the castle allow Howard and Virgil Doyle control over its occupants' minds in the gloom, which is a ghostlike realm that connects all of the consciousnesses of the Doyle family and in which Noemi finds herself an unwilling occupant. In this dreamlike space, Howard and Virgil have complete control of what Noemi sees, feels, hears, and understands; they manipulate her mind in order to break her of her free will and fashion her into a future Doyle bride. At the end of the novel when she is trying to escape, Virgil exercises his control over her body and will by making her disarm herself: "Her fingers ached, and suddenly it felt like she was holding a hot coal in her hand. Noemi let the knife fall to the floor 
with a loud clang and a yelp... She looked down at the knife, which lay by her foot. It was so close, yet she could not pick it up” (286). No matter how clear minded Noemi is within the castle, the network of mushrooms that permeate everything allow Virgil constant control, even when Noemi tries to resist his influence.

However, Noemi is not the simple, aspiring housewife that is expected at the time and the reasoning that she manages while in the gloom makes it difficult for Howard and Virgil to gain control over her. Virgil is so confident in his influence and Noemi’s inability to resist that while he is attempting to rape her, she manages to mislead him into believing that she is complying when she is really bending over the bed to grab the knife that she had hidden there. Unaware that Noemi was not following along with his plan, Virgil is caught off guard when Noemi brandishes her weapon against him and he falls, knocking himself unconscious; before he wakes up, in his pocked "She found [the tincture] it, uncapped it, and drank a little from it, wiping her mouth with the back of her hand. The effect was immediate and noticeable. She felt a wave of nausea, her hands trembled, and the flask slipped from her fingers and shattered on the floor” (261-262). Even while heavily under the influence of Virgil, her mental strength allows her to snap herself out of the mental fog; she saves herself, clears her mind of the mushrooms’ influence, and sets about her escape. She has had too much practice dissecting and understanding the world around her and people's motivations that she is not undone by the confusion of the gloom; rather, the mystery and terror that she experiences motivates her to find out what is going on in High Place and how to stop it.

Similarly, in Mary Shelley’s Frankenstein, the presence of an educated male character sheds an interesting light on the education and intelligence of the contrasting female characters. 
Francis Doyle, the youngest Doyle son who has been neglected since he is not in line to take up the Doyle lineage, provides a noteworthy comparison to Noemi; he has spent his entire life in High Place and he is self-taught in all his education. He did not attend school or university like Noemi and instead gained all his knowledge from books; he has obsessively learned about mushrooms and fungi and his bedroom appears more like a mycologist's lab space where "the table was covered with papers and drawing instruments. She looked at the sharpened pencils, the bottles of india [sic] ink, and the nibs of pens. A box with watercolors, the brushes sitting inside a cup. There were many charcoal drawings, but others were inked. Botanical sketches, the lot of them” (174). However, unlike Noemi his education does not allow him to overcome terror but instead intensifies it. This contrast highlights Noemi’s agency and power that she derives from her ability to reason and understand the complexities of her situation.

Whereas in classic gothic novels, the heroine would have relied on the knowledgeable man to help her escape their situation (like Emily St. Aubert allows herself to be rescued and smuggled away on a ship by Monsieur Du Pont or like Elizabeth Lavenza agrees to wait to plan her wedding to Victor until after he is done mysteriously disappearing just to reappear sickly and with no explanation of what happened and where and why he was gone), Noemi does not rely on anyone within the gothic castle High Place to save her. Not only does she not rely on Francis to rescue her but in fact, she rescues him from his doomed life. Noemi sets the system of mushrooms on fire and all of High Place goes up in flames and "[Noemi and Catalina] each took one of Francis's arms and placed it over their shoulders, half lifting, half dragging him toward the metal gate... He managed to climb several steps with their aid before Noemi was forced to literally drag him up the last couple of steps” (291). While Francis is a source of invaluable knowledge for Noemi when he draws her attention to the mushrooms on the property and their 
value and function, ultimately it is Noemi alone who acts on this knowledge while Francis is terrified into submission and resignation. By partnering Noemi with a powerless and frail male character, Moreno-Garcia diversifies the normal cast of a gothic tale and highlights the power and agency that Noemi's education affords her in terrifying situations.

Early in the novel, Noemi discloses that part of her reasoning for wanting to continue her education beyond her bachelor's degree is that she is not interested in taking on the traditional role of wife and mother. This fixation on requiring women to be wives and mothers is one of the most active and threatening patriarchal structures in the novel; the threat of pregnancy and the concern with continuing the family line in Mexican Gothic is central to the feelings of terror and horror that the story produces. Not only has Noemi actively avoided this role by fighting for her continued education but once the mystery of High Place begins unraveling, she discovers that in the house, women are only good for mass reproduction. Howard, the patriarch, in showing Noemí the portraits of his late wives explains, "that is my second wife. Alice. She was fruitful. A woman's function is to preserve the family line. The children, well, Virgil is the only one left, but she did her duty and she did it well” (Moreno-Garcia 75). Here we see that for the Doyles, women's value lies solely in their reproductive abilities. In Latin American fiction, we often see that, “According to the emergent bourgeois belief system that enshrined the ángel del hogar as an ideal feminine type, women constituted the weaker and more sensitive sex, defined by motherhood and sensibility” (Conway 4). All the women of the family are in fact, procreative tools whose sole purpose is to procreate with Howard and birth him a son whose body he will take, and a daughter who he will use to create his next male body. Here, reproductive ability is the sole purpose of women in the novel and all their value is placed on their ability to be fertile while at the same time, trapping them indefinitely in a male dominated society. 
However, female reproductive power is dominated by Howard's seeming immortality. Moreno-Garcia narrates that, "Howard has lived many lives, in many different bodies. He transfers his consciousness to the gloom and then from the gloom he can live again, in the body of one of his children... three hundred years, maybe more... Florence was still a girl, and even if she'd been older, he would never transmigrate into a woman’s body” (Moreno-Garcia 213, 249). Through a system of powerful mushrooms that infest the house and surrounding grounds, Howard has been able to infuse his consciousness in their network, the gloom, and in a manner similar to male birth, transfer himself from youthful body to youthful body. While he still needs women to physically birth these bodies, he steals them for himself, taking away the female power of creating unique beings as each male in the Doyle line becomes Howard. In this way, while women are invaluable in High Place for their ability to create life, their power is negated by the fact that all male bodies that they reproduce are taken over by Howard and ultimately controlled by the dominant men in the family. Pregnancy in Mexican Gothic is not only a way to force women into their acceptable roles in life, it is a physical threat to unwillingly bind Noemi to a life of subjugation to both her colonizers and patriarchal system.

While the Doyle family has been successfully trapping outside blood into their family for centuries, Noemi's unique position as an educated and intelligent woman overthrows their carefully laid plans. This novel reveals the ways in which the men of society work to oppress and domesticate the women and it highlights the masculine fear of the power of women's bodies, their intelligence, and their independence. Noemí and her cousin Catalina are physically held prisoner in High Place and through the supernaturally cultivated fungal system that Howard and Virgil take control of, the Doyle family attempts to force them into obedience. The mushrooms and fungi occupy every crevice of High Place and their spores are constantly present in the air; 
Noemí's unconscious consumption of these spores pull her into the gloom, where Howard and Virgil exert the power they stole from Agnes, Howard's first wife whose body was sacrifice to create the gloom hundreds of years before and whose body is the hub of all of the gloom's power. In one of her first nights at High Place, Noemí falls asleep and:

She dreamed that the door opened and in walked Howard Doyle... she could not move. An invisible thread anchored her to the bed... he reached out to touch her face, the edge of a nail running down her neck, a thin hand undoing the buttons of her nightdress... he smiled in the dark, white teeth in a diseased, rotting mouth... and she saw it wasn't the old man standing by her bed, studying her limbs, her breasts, starting at her pubic hair. It was Virgil Doyle who had acquired his father’s leering grin... he pressed a hand against her mouth, pushing her back against the bed... and she felt such sweet, sickening desire flowing through her body, making her roll her hips, sinuous, a serpent... and she didn’t want this, not like that, not those fingers digging too firmly into her flesh. (MorenoGarcia 80-81)

The appropriation of the gloom (which is the literal body and mind of the original Doyle matriarch) allows these men unmitigated power over its inhabitants and Virgil specifically abuses this power to continually visit Noemí in her dreams where he sexually assaults her. This domination of Noemí's strong and willful body in her dream space, through a process of fungal infection, allows Virgil power over her that he would not otherwise be able to have. Noemí is too strong, too able, that Virgil must take her body from her and control her subconscious space. The masculine fear of the power of women's bodies shows that through the terror of the gothic genre, Mexican women could speak out and could criticize their roles in a society that regulated them to 
secondary citizens. Women in Mexico at this time were finding their freedom through their voices, their bodies, and their education and were able to grasp power in ways that men had not anticipated; however, the men began to push back against these powers. When Francis asks Noemí, “'You're a woman. Can you do anything you want? Even if it upsets your family?’” she replies, “‘Technically I can, even if I wouldn’t every single time,’” (Moreno-Garcia 136). Noemí’s agency in her life and over her body threatens the patriarchal life that Howard and Virgil live in High Place, so they seek to oppress and dominate her both in her dream space, and by infecting her with the supernatural fungal spores until she submits to them.

\section{Modern Science Mixed with Cultural Superstition}

In talking about the unique complexities of Latin American gothic, the blending of indigenous folklore and mythology with classic tropes of European gothic creates a culturally exceptional evolution of the genre. Similar to the ways in which European gothic used historical times to criticize contemporary concerns, Latin American gothic also pulls from the history and traditions of the regional cultures that came before them. In this way, Latin American gothic works exactly the same as early European gothic except that Latin American historical pasts and concerns were rather different than European ones. In the introduction to her book, Carmen A. Serrano establishes that Latin American authors:

at times syncretize, creolize, and/or hybridize the Gothic genre by infusing their narratives with myths drawn from indigenous beliefs and colonial folktales. By interweaving such cultural references with European Gothic ones, Latin American authors produced distinctive versions of vampires, doppelgangers, and live burials 
that repeat, alter, and/or undermined how these menacing figures and oppressive situations have previously been imagined. The Gothic's imaginative representation of bygone times and monstrous creatures informs Latin expressing trepidation about systems such as authoritarianism, colonization, feudalism, and modernization. (2)

With new cultural histories and experiences, Latin American gothic develops beyond the original parameters of European gothic and incorporates a much larger demographic of cultural values and beliefs. The sources of terror in these works are also broader than the European fears of illegitimacy, bodily harm, and empowered women; Latin American gothic also finds terror in colonization, modernization of traditional values, and religious conflicts. Serrano notes that Latin American authors surpass traditional religious views of the life/death paradigm by drawing influence from Mesoamerican and other worldviews which include cyclical views of life. Unlike European gothic, here death can signify rebirth, continuity, or transmutation (141); similarly, authors like Carlos Fuentes and Julio Cortázar create doppelgangers by using pre-Columbian deities and customs that are, "spectral duplications and reembodiements [sic] of previous historical, literary, and mythical figures; these uncanny revenants, virtual doppelgangers, demand sacrificial victims to secure immortality- an obvious reference to certain pre-Columbian ritualsthus altering the usual literary representations that feature split entities" (142).

Specifically, in Mexican gothic fiction concerns with lingering traditional views and structural oppression are able to be addressed through experiences of terror. Gothic written by women has always been able to subtly expose the double standard for women in society and comment on their mistreatment by patriarchal systems. By tying in indigenous beliefs and 
characters to address specific issues in Mexican society, one aspect of these gothic narratives is the centrality of different classes and gendered experiences that raise questions of structural oppression (Hendricks 328). While this is not the main focus of Moreno-Garcia’s Mexican Gothic, she includes a sharp divide between High Place and the surrounding village of El Triunfo which grew and suffered when the Doyles opened their mine without providing proper safety regulations. While the Doyle family lives in ancient opulence, the surrounding village is exceedingly poor and yet, Noemi finds invaluable allies in the local medicine woman Marta Duval and the town doctor Dr. Camarillo. The local combination of and respect for traditional remedies and modern medicine both stand in stark contrast to the terrifyingly sterile High Place, ruled by the upper class, white, European family. This division of classes with attention to the presence of indigenous values and beliefs reflects the concerns of structural oppression and colonization. Similarly, the writings of women gothic authors in Mexico work to draw attention to concerns of sexuality, desire, and gender boundaries in relation to the new literary spectrum and is often considered “other” by traditional Mexican writings (Estrada, 65). The conflicts between ambition and stereotypical gender roles in Mexican Gothic highlight the changing views of women's sexuality and their space in society.

Mexican Gothic's plot hinges on this gothic mix of European castles and classic gothic tropes with indigenous folklore and local beliefs. For Noemi, this understanding of mycology, anthropology, and the history of High Place work to give her control over her situation, to lessen her fear as she understands how her surroundings function, and allow her to end the horrors happening at High Place where no one could in the past. Considering that the entire supernatural aspect of the novel is built through a system of mystical mushrooms, the scientific field of mycology, the study of mushrooms and fungi, becomes an indispensable fountain of knowledge 
for Noemi. It allows her to regain control of her mind and body to escape. As Noemi begins to unravel the mystery of Howard Doyle’s immortality, she learns of his discovery of the mushroom that prolongs life which had been, up until his discovery, fiercely protected by an indigenous community; Howard convinces some of the locals to take him to their sacred place and when he arrives, "There was a priest too, an old man who tended to the altar of their god. For in the end this was indeed a holy site of a strange sort. Instead of candles, the fungus hanging from the cave walls, luminescent, lit a crude alter... they used the fungus to heal their wounds and preserve their health, but it could be so much more" (205-206). While the Indigenous people think they are sharing their beliefs and values with Howard, he is plotting how to utilize this power for his own benefit. This mix of indigenous belief and folklore with contemporary scientific applications creates the terrifying system of mushrooms that permeates the castle and all its inhabitants and allows the power-hungry patriarch a semblance of eternal life. The inclusion of local superstition in the creation of this work of terror adds a new dimension to the fear of colonialism and to the novel as well; not only is the gloom a terrifying semi-sentient being, but its creation is solely caused by the invasion of Europeans and the pillaging of the indigenous valuables. Without the local understanding of the mushroom, the creation of the gloom would not have been possible in the first place. Noemi here is the perfect heroine for this mixed folkloric/scientific supernatural entity; her heritage allows her an understanding of cultural beliefs that the Doyle's do not possess and her intelligence and rigorous education allow her to understand the scientific ways in which the sacred mushrooms have been perverted.

The combination of indigenous mushrooms with the typical gothic plot in MorenoGarcia's work allows her to draw attention to interesting ways in which women are mistreated and misused in traditional patriarchal societies. While the most powerful entity in the novel is 
unquestionably the gloom, Howard and Virgil both wield its power as their own and use it to subject Noemi to psychologically traumatizing terrors. However much Howard and Virgil claim to control the gloom's power, it is created by and through Howard's first wife, and she is the living and breathing consciousness of the network. The men of the family are literally manipulating and using the power of the wife/mother figure as their own and have hidden her away to mummify in the family crypt. Upon this discovery, Noemi realizes that:

\begin{abstract}
All the ghosts were Agnes. Or rather, all the ghosts lived inside Agnes. No, that wasn’t right either. What had once been Agnes had become the gloom, and inside the gloom there lived ghosts. It was maddening. It was not a haunting. It was possession and not even that, but something she couldn't even begin to describe. The creation of an afterlife, furnished with the marrow and the bones and the neurons of a woman, made of stems and spores. (284)
\end{abstract}

As Howard attempts to live forever by recreating and birthing himself repeatedly, the true power lies in the womb of Agnes, as she births the entire system of fungi that the Doyle family depend on for their lives. The use of mycology, the study of mushrooms and fungi, in the novel is an interesting aspect of medical science that informs the characters. Mushrooms have been used for centuries in traditional medicine and multiple drugs have been created from fungi; there are also several mushrooms that have mind-altering properties in human consumption ("Mycology”). In explaining the history of mushrooms and fungi in Mexico, Francis points out to Noemi that, “The Zapotec Indians of your country practiced dentistry by giving people a mushroom which would intoxicate them and serve as an anesthetic. And the Aztecs, they too found mushrooms interesting. They consumed them in order to experience visions” (Moreno-Garcia 99). These 
scientific uses when combined with indigenous lore create a supernatural power that, if you are able to suspend your belief, follows strict reason and operates fairly rationally. Howard's wife, though left for dead, passes on her consciousness through a creation of medicinal mushrooms in a perverse cycle of birth that plays on the Latin American understanding of the cyclical life/death paradigms- the longer she has been enshrouded by the mushrooms, the more she breeds and her creation of the gloom grows more powerful. The gloom operates as a hallucinogen, creating a dream-like space that connects all the consciousnesses in the house. Agnes's power is so incredibly strong that Noemí cannot tell the difference between her imagination and the gloom.

Similarly to the mixture of folklore and modern science, Noemi’s study of anthropology and Howard Doyle’s fascination with anthropological theories represents the conflict between traditional worldviews and progressive ones. The novel addresses questions of race, sexuality, and education through the villain of the novel, Howard Doyle, who is obsessed with the ideas of beauty and race and fills his library with ancient anthropological works about the superiority of certain races. Upon his first interaction with Noemi, he establishes his belief in the superiority of his race, having immigrated from England, to Noemí’s “Indian heritage”. He asks her, “do you believe as Mr. Vasconcelos does that it is the obligation, no, the destiny of the people of Mexico to forge a new race that encompasses all races? A bronze race? This despite the research of Davenport and Steggerda?... What are your thoughts on the intermingling of superior and inferior types?” (Moreno-Garcia 29-30). His interest in Noemí is sparked by her intelligence and her independence and his attention shifts to her from her cousin Catalina who has just married Howard's son, Virgil. The situation makes Noemí uncomfortable as she first becomes aware of Howard's perverse focus on anthropological and genetic science- he is suspiciously concerned with the aesthetic features of his descendants and adding the "exotic" genes of Noemí to his 
family pool. While this obsession is clearly Howard's desire to create himself the optimal vessel to inhabit, it represents traditional views of race and sexuality in conflict with more modern and tolerant views; everything that Howard is looking for- a beautiful woman to bear him the perfect children- is the opposite of what Noemi desires for her life. His old-fashioned ideas that women are good for being aesthetically pleasing and for producing children clash with Noemi's view of her agency, intelligence, and her ambitions for her life outside of the home. Howard's wicked desire for eternal life and his need for a strong and healthy familial line literally traps Noemi in the house and threatens her independence with forced pregnancy.

\section{The Modern Gothic}

Analyzing a gothic novel from over two-hundred years after the inception of the genre and from a different culture from across the Atlantic has allowed me to notice several important conceptions of terror, women's experience of it, its relationship to women's education and their access to typically coded masculine education, and the evolution of these concepts in the past two-hundred years. In this collection of work, I defined terror as a sustained experience that affects daily life and as something that women experience on a much greater scale than men; using Moreno-Garcia’s Mexican Gothic, I have noted the ways in which women in more modern eras and in Latin American countries experience fear in many of the same ways that women of eighteenth and nineteenth century Europe did. While the cultural differences affect the socialization of fear in unique ways, regardless of background, women authors of gothic literature most often find terror in patriarchal oppression and gender stereotyped roles that limit their agency, access to education, and control over their own bodies. Moreno-Garcia's Noemi 
fights against the assumption that she will immediately become a wife and mother, against the threat of marriage and pregnancy that the Doyle’s force on her, and against the control over her body and mind that the gloom allows Howard and Virgil to have. If I was looking for an evolution in the root cause of women's terror between Radcliffe’s Mysteries of Udolpho and Moreno-Garcia’s Mexican Gothic, I would have been disheartened; while the naming of the fear might have changed in the last two hundred years (the fear of lost purity has become simply the fear of violation), the cycle of fear that men enact on women has continued to use the same methods to avenge their deeply rooted fear of women's power. While this novel crosses time and cultures, the same is still true of the terror that women experience living in a male-dominated society.

The evolution of women's education, their access to it, and the societal perceptions of it, however, have evolved in a less pessimistic manner. While Radcliffe’s heroine coped with and survived terror through her domestic education and her spatial knowledge, Shelley’s Elizabeth and Safie were academically education as a means to enable male education, here MorenoGarcia’s Noemi actively pursues higher education and is fighting for the ability to get her Master's degree at the beginning of the novel. The level of education that is socially acceptable for women in these novels has slowly progressed; while there is serious pushback from Noemi's family about her ambitions, the fact that she was allowed to attend university at all is something that neither Radcliffe nor Shelley could ever have hoped for. Just like the first two novels I analyzed, Noemi's education is what allows her the upper hand in her gothic situation and quite literally saves her from the domestic enslavement of marriage into the Doyle family. While the root of women's terror and their experiences with this perpetual cycle of terror have not changed, the level of access to education that they can achieve has and has transformed the gothic heroine 95 
from a brave but beautiful face that the action happened to into an active, independent woman who rescues not only herself, but others who rely on her.

Understanding and discussing the ways in which the gothic genre has evolved since its beginnings in the late eighteenth century demonstrates the ways in which the genre has remained incredibly relevant and an important vessel for pointing out social and cultural fears and failings. Latin American gothic mixes classic tropes with "indigenous beliefs and colonial folktales, thereby creating an innovative version of a Gothic villain that undermine how these figures have previously been imagined... but rather evokes the Gothic to speak of something else, and this might explain why critics at times see the text as unsuccessful because it does not follow the conventions or plot one would expect from a Gothic tale" (Serrano 172). The gothic genre has unfortunately been very narrowly defined in past scholarship and the emphasis on "feminine" terror and "masculine" horror have has delineated the genre as a very specific type of text from a specific time period; however, by taking a modern, post \#Metoo perspective and redefining definitions of terror and horror, I have shown how gothic texts are still important methods of expressing women's feelings of terror and are not limited by race, culture, sexuality, or class. Latin American gothic's fusion of traditional mythology and beliefs with what are considered gothic convention have created new, innovative ways of writing and interpreting the genre that provide a crucial insight into the ways that women are still victims of the cycle of terror. As women continue to experience fear, they continue to turn to "monsters, including the newer versions of vampires and zombies,” which in turn, “continue to embody multifaceted, intangible, and nameless fears, and evoking them is one way to allegorize these anxieties” (185). 


\section{REFERENCES}

Barbauld, Anna Laetitia. Lessons for Children. New ed. London: Longman and Co., 1867. Google Books.

Behn, Aphra. The History of the Nun. London, 1689. PDF.

Brewster, Claire and Keith Brewster. “’Patria, Honor y Fuerza’: A Study of a Right-Winged Youth Movement in Mexico during the 1930s-1960s.” Journal of Latin American Studies vol. 46, 2014, pp. 691-721. JSTOR, www.jstor.org/stable/24544334. Accessed 23 Nov. 2020.

Buckley, Jenifer. Gender, Pregnancy and Power in Eighteenth-Century Literature The Maternal Imagination. 1"s ed. Cham: Springer International Publishing, 2017. Print.

Chandler, Anne. “Ann Radcliffe and Natural Theology.” Studies in the Novel, vol. 38, no. 2, (2006): 133-153. Print.

Cherniavsky, Eva. “Keyword 1: \#MeToo.” Differences, vol. 30, no. 1 (2019): 15-23. Print. Cohen, Michele. “The Pedagogy of Conversation in the Home: 'Familiar Conversation' as a Pedagogical Tool in Eighteenth and Nineteenth-Century England.” Oxford Review of Education, vol. 41, no. 4, (2015): 447-463. Print.

Conway, Christopher. “SISTERS AT WAR: Mexican Women's Poetry and the U.S.-Mexican War.” Latin American Research Review, vol. 47, no. 1, 2012, pp. 3-15. JSTOR, www.jstor.org/stable/41413327. Accessed 24 Nov. 2020.

Dalley, Lana L., and Kellie Holzer. "Victorian Literature in the Age of \#MeToo [Special Issue].” Nineteenth-Century Gender Studies, vol. 16, no. 2 (2020). Print. 
DeLamotte, Eugenia C. Perils of the Night: a Feminist Study of Nineteenth-Century Gothic. New York: Oxford University Press, 1990. Print.

Edelman, Diana Perez. “Gothic Medicine: Murderous Midwives and Homicidal Obstetricians.” Gothic Studies, vol. 20, no. 1-2, (2018): 227-242. Print.

Edgeworth, Richard Lovell, and Edgeworth, Maria. Practical Education. New York: Harper and Brothers Publishers, 1855. Google Books.

Ellis, Kate Ferguson. The Contested Castle: Gothic Novels and the Subversion of Domestic Ideology. Urbana: University of Illinois Press, 1989. Print.

Estrada, Oswaldo. “AGAINST REPRESENTATION: WOMEN'S WRITING IN CONTEMPORARY MEXICO.” Hispanófila, no. 157, 2009, pp. 63-78. JSTOR, www.jstor.org/stable/43808577. Accessed 24 Nov. 2020.

Gilbert, Sandra M., and Susan Gubar. The Madwoman in the Attic: the Women Writer and the Nineteenth-Century Literary Imagination. New Haven: Yale University Press, 984. Print.

Haekel, Ralf, and Sabine Blackmore. Discovering the Human Life Science and the Arts in the Eighteenth and Early Nineteenth Centuries. Goettingen: V\&R Unipress, 2013. Print.

Halsey, Katie. "The Home Education of Girls in the Eighteenth-Century Novel: ‘The Pernicious Effects of an Improper Education.'” Oxford Review of Education, vol. 41, no. 4, (2015): 430-446. Print.

Hansen, Mascha. “Scientifick Wives- Eighteenth-Century Women Between Self, Society and Science.” Haekel and Blackmore, pp. 53-68. 
Hedrick, Tace. “'The Spirits Talk to Us’: Regionalism, Poverty, and Romance in Mexican American Gothic Fiction.” Studies in the Novel, vol. 49, no. 3, (2017): 322-340. Print. Holmes, Richard. "Mary Shelley and the Power of Contemporary Science.” Frankenstein: the 1818 Text, Contexts, Criticism. Ed. J. Paul Hunter. $2^{\text {nd }}$ ed. New York: W.W. Norton \& Co., 2012, pp. 183-194. Print.

Hume, Robert. “Gothic versus Romantic: A Revaluation of the Gothic Novel.” PMLA 84 (1969): 282-290. Print

Jennings, Kristine. "Novel Genders: Women Writing Women in the Eighteenth Century.” Studies in the Literary Imagination, vol. 47, no. 2, (2014): v-xvii. Print.

Johnson, Elizabeth. “’Deadly Snares’: Female Rivalry, Gender Ideology, and EighteenthCentury Women Writers.” Studies in the Literary Imagination, vol. 47, no. 2, (2014): 121. Print.

Kohler, Ulrike Kristina. “Ann Radcliffe’s Gothic- A Subtle Plea for Female Education in the Arts and in the Sciences.” Haekel and Blackmore, pp. 105-114.

Ledoux, Ellen Malenas. Social Reform in Gothic Writing Fantastic Forms of Change, 17641834. New York: Palgrave Macmillan, 2013. Print.

Lopez, Oresta. "Women teachers of post-revolutionary Mexico: feminization and everyday resistance.” Paedagogica Historica, vol. 49, no.1, 2013, pp. 56-69. EBSCOhost, doi:10.1080/00309230.2012.746714. Accessed 23 Nov. 2020.

Martin, Judith E. “Luise Muhlbach’s Aphra Behn (1849): Auto/Biography of a Woman Artist.” Neophilologus, vol. 90, no. 4 (2006): 585-600. Print. 
McDermott, Lydia. "Birthing Rhetorical Monsters: How Mary Shelley Infuses Metis with the Maternal in Her 1831 Introduction to Frankenstein.” Rhetoric Review, vol. 34, no.1, 2015, pp. 1-18. Print.

Mellor, Anne K. “Possessing Nature: The Female in Frankenstein.” Frankenstein: the 1818 Text, Contexts, Criticism. Ed. J. Paul Hunter. 2nd ed. New York: W.W. Norton \& Co., 2012, pp 355-368. Print.

Miles, Robert. “’Mother Radcliffe’: Ann Radcliffe and the Female Gothic.” The Female Gothic New Directions, edited by Diana Wallace and Andrew Smith, Palgrave Macmillan, 2009, 42-59.

Miller, Adam. “Ann Radcliffe’s Scientific Romance.” Eighteenth-Century Fiction, vol. 28, no. 3, (2016): 527-545. Print.

Moers, Ellen. “Female Gothic: The Monster’s Mother.” Frankenstein: the 1818 Text, Contexts, Criticism. Ed. J. Paul Hunter. 2nd ed. New York: W.W. Norton \& Co., 2012, pp 317-327. Print.

Moers, Ellen. Literary Women: The Great Women Writers. Garden City, NY: Doubleday, 1976. Print.

Moreno-Garcia, Silvia. Mexican Gothic. First edition. New York: Del Rey, 2020. Print. “Mycology.” Wikipedia, 19 Nov. 2020, https://en.wikipedia.org/wiki/Mycology\#: :text=Mycology\%20is\%20the\%20branch\%20 of,such\%20as\%20toxicity\%20or\%20infection. Accessed 23 Nov. 2020.

Radcliffe, Ann. Mysteries of Udolpho. Oxford University Press, 1970. 
Rankin, Monica A. "La ropa cosmica: Identity and Fashion in 1940s Mexico.” Studies in Latin American Popular Culture, vol. 28, 2010, pp. 95-111. EBSCOhost, search.ebscohost.com/login.aspx?direct=true\&db=mzh\&AN=2011320487\&site=ehostlive\&scope=site. Accessed 23 Nov. 2020.

Roulston, Chris. "Space and the Representation of Marriage in Eighteenth-Century Advice Literature.” The Eighteenth Century: Theory and Interpretation, vol. 49, no. 1 (2008): 25-41. Print.

Sandock, Mollie. "Learned Ladies: Misogyny and the English Novel.” Misogyny in Literature, edited by Katherine Anne Ackley, Garland Publishing, 1992, 143-164.

Schaible, Karl Heinrich. "The state and education: an historical and critical essay, with special reference to educational reform.” JSTOR Primary Sources, 1 Jan. 1870. JSTOR, www.jstor.org/stable/10.2307/60202775. Accessed 9 Dec. 2020.

Serrano, Carmen A. Gothic Imagination in Latin American Fiction and Film. Albuquerque: University of New Mexico Press, 2020. Print.

Shelley, Mary edited by J. Paul Hunter. Frankenstein: the 1818 Text, Contexts, Criticism. $2^{\text {nd }}$ ed. New York: W.W. Norton \& Co., 2012. Print.

Wallace, Diana, and Andrew Smith. The Female Gothic New Directions. New York: Palgrave Macmillan, 2009. Print.

Wallace, Diana. “'The Haunting Idea’: Female Gothic Metaphors and Feminist Theory.” The Female Gothic New Directions, edited by Wallace and Smith, New York: Palgrave Macmillan, 2009. pp. 26-41. 
Walpole, Horace. The Castle of Otranto. Oxford University Press, 2014.

Winter, Kari. "Sexual/Textual Politics of Terror” in Misogyny in Literature: An Essay Collection, edited by Katherine Anne Ackley. New York: Garland Publishing, 1992, 89101.

Wollstonecraft, Mary, and William Godwin. A Vindication of the Rights of Women. [2nd ed.] London, 1792; and, Memoirs of the author of A vindication of the rights of women [by] William Godwin. London, 1798. Farnborough: Gregg, 1970. Print.

Wozolek, Boni. "Hidden Curriculum of Violence: Affect, Power, and Policing the Body.” Educational Studies: Journal of the American Educational Studies Association, vol. 56, no. 3 (2020): 269-285. Print. 